Article

\title{
The Hidden Burden of Food Waste: The Double Energy Waste in Italy
}

\author{
Matteo Vittuari *, Fabio De Menna and Marco Pagani \\ Department of Agricultural and Food Sciences, University of Bologna, Viale Fanin 50, 40124 Bologna, Italy; \\ fabio.demenna2@unibo.it (F.D.M.); markpagani@gmail.com (M.P.) \\ * Correspondence: matteo.vittuari@unibo.it; Tel.: +39-051-209-6161 \\ Academic Editor: Ling Kong
}

Received: 22 March 2016; Accepted: 29 July 2016; Published: 19 August 2016

\begin{abstract}
The energy intensity of modern food systems represents a major issue in a scenario of decreasing oil resources and increasing population. Beside the use of renewable energy, an increased efficiency in food systems could contribute to reduce fossil fuels dependence. In this sense, food losses and waste (FLW) have crucial consequences on the energy balance. Based on the concept of "embodied energy", food wastage can be framed as a double waste of energy, both in terms of non-consumed food energy and the inputs used for production. Secondary data regarding direct and indirect energy inputs and FLW have been collected for the Italian food chain to estimate the embodied energy of food waste. Since in 2011 the production and distribution of food implied the use of $822 \mathrm{PJ}$ and $18 \mathrm{Mt}$ of food was discarded, $67 \mathrm{PJ}$ of food energy and $100 \mathrm{PJ}$ of embodied energy were wasted. These figures are equivalent to $12.2 \%$ of the total nutritional energy output and to $1.3 \%$ of the final energy use in Italy, respectively. The concept of double energy waste sheds new light on the intertwined relationship between energy and food security, suggesting that appropriate food waste reduction policies could result in a higher food production level and relevant energy savings.
\end{abstract}

Keywords: food waste; energy waste; sustainable food systems; Italy

\section{Introduction}

Since the world energy crisis during the 70s, the dependence on fossil fuels and other non-renewable resources has been acknowledged as a structural limit of the current socio-economic development model [1-3]. In a perspective of increasing world population, the current pattern of natural resource exploitation could endanger the sustainability of modern life styles. Therefore, the access to an adequate amount of resources should drive the transition towards a smart, equitable and sustainable use of energy, food, and water [4-8].

In this framework, there is a greater awareness of food production, not only as a basis for human life, but also as one of the most energy intensive economic activities. Historically, food production gradually increased its energy use in order to sustain a larger share of non-agricultural workers. This was obtained through the replacement of human and animal power with water and wind first, and the steam tractor later. The unmatched yields, granted by the "Green Revolution", led to the satisfaction of basic food needs in most of the industrialized countries. Nevertheless, the intensive use of machineries, fertilizers, electric irrigation, and plastic also caused relevant environmental and economic consequences [6,9-11].

Energy statistics do not usually expose the relevance of food production in terms of final energy use. The traditional division between economic sectors only reveals the residual share attributable to agriculture and forestry [12].

Nonetheless, when a system approach is adopted, food systems can represent up to the $30 \%$ of final energy use [11]. A considerable use of energy can be attributed to downstream segments such 
as processing, packaging, distribution and consumption of food. Therefore, the energy efficiency of food systems is rather low: for example, in the US, $10 \mathrm{kcal}$ of fossil fuel energy are required in order to produce one kcal of food $[11,13,14]$. Likewise, a similar perspective allows estimating that the sole production of animal derived food implies an 18\% share of global greenhouse gas (GHG) emissions, equivalent to industry and higher than transports [15-18]. Therefore, changes in food choices might have the same magnitude as modifications in mobility patterns [19].

The energy intensity of food systems also implies relevant socio-economic consequences. The recent food crisis revealed the profound interactions between food and energy markets [20,21]. In general, during the first decade of the XXIst century, global staple food prices followed almost immediately oil market trends [22]. This matching pattern posed a serious pressure on food security in developing countries and increased the vulnerability of production systems to energy costs, especially for small farmers [23].

Despite this energy burden, contemporary food systems entail a similarly excessive creation of residual biomass. A share of this inefficiency is intrinsically linked to production processes, as in the case of pruning, cultivation and processing by-products, inedible waste and potentially hazardous waste as used vegetable oil [24]. On the other hand, a relevant share (one-third of food produced for human consumption) is represented by losses and waste of edible food products, or parts, along the whole food supply chain (FSC) [25-28].

This often unexploited biomass should be perceived as a systemic inefficiency contributing to the depletion of limited resources, such as water, land, and fertilizers [29], as well as economic value [30]. In particular, food losses and waste (FLW) can be considered as a "double waste" of energy, because, on one hand the chemical energy contained in food, and, on the other hand the production energy inputs are wasted alongside with food $[13,31]$.

Notwithstanding, while embodied energy is a quite established concept, its application to food waste remains limited. Few recent studies attempted to estimate resources embodied in food waste $[29,32,33]$ and only one focused on energy [13]. Thus, this paper elaborates on the concept of "double waste" embedded in FLW through the application of an analytical model for the assessment of embodied energy in food waste in the Italian FSC, which is characterized by a relevant use of energy [34] and by considerable amounts of edible FLW along the whole chain [27].

\section{Materials and Methods}

The assessment of the embodied energy wasted in FLW of the Italian FSC was structured in four main stages:

- $\quad$ Assessment of the total direct and indirect energy inputs in the different segments of the FSC;

- Calculation of the embodied energy per unit of mass in Italian food;

- Quantification of the extra energy input for animal-derived food;

- $\quad$ Final estimation of the energy embodied in FLW in FSC segments.

The following segments of the FSC were analyzed: farming, processing (including packaging), logistics, and distribution. Household consumption was not considered, since no reliable data were available in Italy on home energy inputs for food conservation and cooking. Consequently, also the end-of-life of products was not considered, since it occurs after household consumption.

All data utilized and elaborated in this work are referred to Italy, with the exception of:

- energy intensity of chemicals and plastics since these products are similar across countries, therefore differences are negligible;

- $\quad$ energy intensity of transport, since differences are not relevant across countries.

Percentages of wasted mass that were applied to Italian production data since European averages represent the more reliable estimates of food waste available at July 2016. 


\subsection{Assessment of Energy Inputs of the FSC}

Energy inputs of the Italian FSC were analyzed according to the framework presented in Figure 1. Inputs (red arrows) are split into direct (energy use in process operations) and indirect inputs (energy embodied in materials or machinery used in the chain). Figure 1 shows also biomass flows of raw (green arrows) and processed products (black arrows). Logistics is divided into two segments only for conceptual and graphical clarity, because it has been analyzed as a whole, according to available data (see Section 2.1.3).

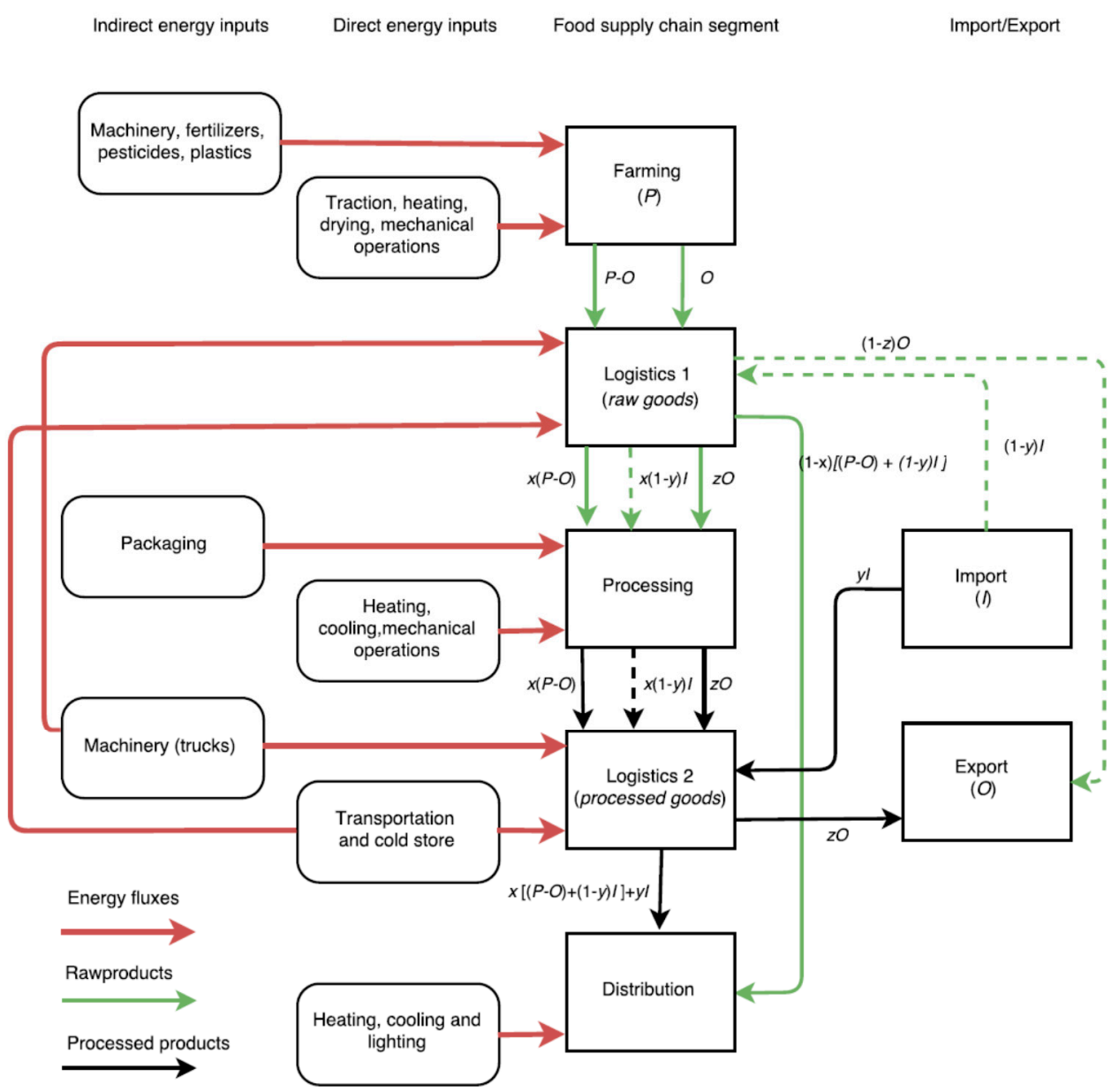

Figure 1. Flow chart of Italian FSC with direct and indirect energy inputs and raw and processed biomass fluxes; $x, y$ and $z$ are the fractions of processed food in national production, import and export, respectively (see Section 2.2). Products for animal feed are not indicated.

All energy inputs associated with food produced on Italian territory, both for internal consumption and for export, were considered in the present study. Thus, the analysis focuses only on energy consumed in Italy, including energy used for exported food, while the energy burden of the imported food was not accounted for, since in this approach, it is symmetrically attributed to the country of origin. For the same reason, international transportation energy for imported food was not considered.

For each fuel, lower heating values and refinery efficiencies $\eta$ were considered, so that $1 \mathrm{MJ}$ of net energy is equivalent to $1 / \eta \mathrm{MJ}$ of gross primary energy (see Table A1 of Appendix). In the period 2000-2014 the primary energy equivalent of one joule of electrical energy decreased from $2.25 \mathrm{~J}$ to $1.55 \mathrm{~J}$ owing to the great development of renewable energies, wind, photovoltaic and, to lesser extent, hydroelectric. For instance, in 2014 every J of final use, $0.366 \mathrm{~J}$ came from renewable sources; the 
remainder $0.633 \mathrm{~J}$ of final energy came from $1.19 \mathrm{~J}$ of primary fossil fuels (coal gas and oil); see details in Figure A1 of the Appendix.

\subsubsection{Farming}

Energy utilized at the farm level $\left(E_{f a r m}\right)$ is composed of four different main contributions: (i) direct inputs for the production of food and animal feed; indirect inputs from (ii) machinery; (iii) fertilizers and pesticides and (iv) plastic materials.

(i) Direct energy use data for farming operations (fuel for traction, irrigation, heating, drying, electrical energy for mechanical operations and lighting) were obtained from the Italian national energy balance [35] split by fuel type. Direct use of fuel for fisheries was also considered.

(ii) The energy equivalent of machinery was estimated in approximately $140 \mathrm{MJ}$ for every $\mathrm{kg}$ of equipment $[36,37]$. This value is quite high, as it accounts not only for production (around $80 \mathrm{MJ} / \mathrm{kg}$ ), but also for maintenance and repair. This figure has been substantially confirmed by a more recent analysis on tractors and relative equipment [38]. The number of new tractors entered in use in Italy for the years 2000-2014 was retrieved from the professional association [39]. A mass/power ratio of $60 \mathrm{~kg} / \mathrm{kW}$ was considered [40], while the average power is roughly $90 \mathrm{~kW}$ (average over 26,000 tractors on sale in June 2014 on the site www.agriaffaires.it (accessed on 21 January 2016); the average tractor mass was therefore assumed to be $5.4 \mathrm{t}$, and the average energy input per tractor is $745.8 \mathrm{GJ}$.

(iii) Data for nitrogen $(\mathrm{N})$, phosphate $(\mathrm{P})$ and potash $(\mathrm{K})$ fertilizers use in Italian agriculture were sourced from national and international databases [41,42]. Average specific energy inputs for fertilizers are assumed to be $49 \mathrm{MJ} / \mathrm{kg}$ for urea, 42 for ammonium sulfate, 13 for simple perphosphate and 19 for triple perphosphate [43], 40.6 MJ $/ \mathrm{kg}$ for ammonium nitrate [44], $5 \mathrm{MJ} / \mathrm{kg}$ for potassium sulfate and chloride, 18 and $31 \mathrm{MJ} / \mathrm{kg}$ for NP and PK fertilizers, respectively [45], 6 and $7 \mathrm{MJ} / \mathrm{kg}$ for NK and NPK fertilizers, respectively [46,47]. Data for pesticides use were obtained from FAO [48], while average specific energy inputs are assumed to be $310 \mathrm{MJ} / \mathrm{kg}$ for herbicides and insecticides and $220 \mathrm{MJ} / \mathrm{kg}$ for fungicides [49-53].

(iv) The use of plastic material in agriculture (tunnels, mulching, nets, piping and containers) was documented by Scarascia-Mugnozza et al. [54]. Input energy for plastics production at farm level was assumed to be $79 \mathrm{MJ} / \mathrm{kg}$, as an average of the most used polymers in agriculture: polyethylene [55] and polypropylene [56].

\subsubsection{Food Processing and Packaging}

Energy use in the food transformation industry $\left(E_{\text {proc }}\right)$ is the sum of direct energy use and energy use for packaging. Direct energy utilized in mechanical processes, cooking, freezing, and space heating/cooling related to the food industry was retrieved from the national energy balance [35] split by fuel type. The small quote of energy related to the processing of feed $F e_{B}$ that is not part of the human FSC (see Section 2.2) was subtracted from the MSE data.

Energy use for packaging was computed by multiplying specific embodied energy (see Table A2 in Appendix) by total masses of food packages. For each material, data and percentage of usage in the food sector were estimated from Iascone et al. [57] and the Italian Packaging Institute [58], with the exception of wood pallets [59].

\subsubsection{Transport Logistics}

Energy use for food transport $\left(E_{\text {tran }}\right)$ was computed by multiplying masses-distance products $(\mathrm{t}-\mathrm{km})$ by energy intensity values $(\mathrm{GJ} / \mathrm{t}-\mathrm{km})$ for each transport mode; this value has been detailed for national $\left(E_{\text {tran-n }}\right)$ and international $\left(E_{\text {tran-i }}\right)$ transport. Since only energy associated with export was accounted for in the present study and no separate statistics were available for import/export masses-distances products, energy associated to food exports $\left(E_{\text {tran-ex }}\right)$ was obtained as the quote 
of energy for international transport corresponding to the quote of exportations with respect to international trade:

$$
E_{\text {tran }-e x}=E_{\text {tran }-i} \frac{O}{O+I}
$$

where $O$ and $I$ are the masses of food exported and imported, respectively (see Table 1).

Masses-distances products for road and rail transport were reported by Eurostat [60,61], both for national and international traffic. According to different analysis relative to Europe or Italy, an energy intensity of $3.0 \pm 0.2 \mathrm{MJ} / \mathrm{t}-\mathrm{km}$ and $0.3 \pm 0.02 \mathrm{MJ} / \mathrm{t}-\mathrm{km}$ was used, for road and rail transport, respectively [62-65]. The energy intensity value for road freight, which is higher than the typical consuming of heavy goods vehicles [66], takes into account the fact that in approximately $30 \%$ of the voyages the trucks are empty [67].

Mass-distances products for sea transport were not directly available, therefore they were computed for national and international routes. For internal transport the routes among the 17 Italian ports that cover roughly $70 \%$ of the traffic between regions (while $10 \%$ of the traffic is within regions) were considered. Distances were computed using a Geographic Information System software and averaged using as weights the volumes of traffic along the routes, leading to a weighted average sea distance of $565 \mathrm{~km}$. This value was multiplied by the masses of food loaded or unloaded at the ports [68].

For international sea transport, $85 \%$ of sea traffic to and from Italy corresponds to just 27 countries. The $87 \%$ of this traffic is directed to/from 13 Italian ports. The distances between those countries and these ports were estimated using a GIS software. A weighed average distance for each country was computed, using as weight the volume of traffic in each Italian port. These values were multiplied by the masses of food loaded or unloaded at the ports [68].

The energy intensity of bulk carrier ships was determined by the expression $e_{\text {ship }}=0.024+$ $0.827 / \mathrm{DWT}(\mathrm{MJ} / \mathrm{t}-\mathrm{km})$, where DWT is the ship deadweight [69]. Typical values range from $0.1 \mathrm{MJ} / \mathrm{t}-\mathrm{km}$ for smaller ships $(10,000 \mathrm{t}$ ), to $0.029 \mathrm{MJ} / \mathrm{t}-\mathrm{km}$ for the largest ships $(150,000 \mathrm{t})$. The average energy intensity was computed taking into account the distribution of ships among the five commercial classes, Handysize, Handymax, Supramax, Panamax and Capesize [70], leading to an average value of $0.035 \mathrm{MJ} / \mathrm{t}-\mathrm{km}$.

\subsubsection{Distribution}

Energy utilization in the distribution sector $\left(E_{\text {dist }}\right)$ was calculated by multiplying retail areas by energy intensity per unit area. Global areas of retail stores attributable to food were obtained from Magelli [71], and split for hypermarkets, superstores, supermarkets and small dealers. In ten years (2004-2014), retail areas increased from 11 to 17 million square meters.

According to an analysis of a sample of 46 superstores and hypermarkets, the intensity is $1275 \pm 110 \mathrm{MJ} / \mathrm{m}^{2}$ year for electrical energy and $150 \pm 23 \mathrm{MJ} / \mathrm{m}^{2}$ year for thermal energy [72]. These values were converted in primary energy equivalents according to the conversion factors of Table A1 (gas) and Figure A1 (electrical energy).

Table 1. Mass balance of the Italian food supply chain (FSC) (in Mt).

\begin{tabular}{lcccccccc}
\hline$j$ & $\begin{array}{c}\text { Product } \\
\text { Type }\end{array}$ & $\begin{array}{c}\text { Production } \\
(\mathbf{P})\end{array}$ & $\begin{array}{c}\text { Import } \\
(\mathbf{I})\end{array}$ & $\begin{array}{c}\text { Export } \\
(\mathbf{O})\end{array}$ & $\begin{array}{c}\text { Supply } \\
(\mathbf{S})\end{array}$ & $\begin{array}{c}\text { Food } \\
(\text { Fo) }\end{array}$ & $\begin{array}{c}\text { Feed } \\
(\mathbf{F e})\end{array}$ & Other \\
\hline 1 & Cereals & 19.03 & 12.03 & 5.04 & 25.33 & 9.45 & 14.08 & 0.98 \\
2 & Tubers & 1.56 & 1.54 & 0.17 & 2.89 & 2.35 & 0.06 & 0.48 \\
3 & Pulses & 0.14 & 0.29 & 0.02 & 0.41 & 0.29 & 0.09 & 0.03 \\
4 & Soybeans & 0.57 & 4.20 & 0.28 & 4.48 & - & 4.28 & 0.21 \\
5 & Oilseeds & 3.56 & 0.59 & 0.15 & 4.01 & 1.88 & 0.05 & 0.04 \\
6 & Sugar crops & 3.55 & - & - & 3.55 & 1.65 & - & 0.05 \\
7 & Vegetables & 14.29 & 1.99 & 5.76 & 10.52 & 8.78 & 0.55 & 1.20 \\
8 & Fruits & 17.65 & 2.77 & 4.72 & 15.71 & 8.55 & - & 0.67 \\
\hline
\end{tabular}


Table 1. Cont.

\begin{tabular}{|c|c|c|c|c|c|c|c|c|}
\hline$j$ & $\begin{array}{l}\text { Product } \\
\text { Type }\end{array}$ & $\begin{array}{l}\text { Production } \\
\text { (P) }\end{array}$ & $\begin{array}{c}\text { Import } \\
\text { (I) }\end{array}$ & $\begin{array}{l}\text { Export } \\
\text { (O) }\end{array}$ & $\begin{array}{l}\text { Supply } \\
\text { (S) }\end{array}$ & $\begin{array}{l}\text { Food } \\
\text { (Fo) }\end{array}$ & $\begin{array}{c}\text { Feed } \\
(\mathrm{Fe})\end{array}$ & Other \\
\hline 9 & Wine, beer & 6.34 & 1.22 & 3.08 & 4.87 & 3.65 & - & 0.39 \\
\hline 10 & Meat & 5.07 & 2.18 & 0.95 & 6.3 & 6.13 & - & - \\
\hline 11 & Milk & 11.22 & 8.02 & 2.37 & 17.09 & 15.95 & 0.58 & 0.32 \\
\hline 12 & Eggs & 0.76 & 0.04 & 0.04 & 0.75 & 0.71 & - & 0.04 \\
\hline 13 & Fish & 0.39 & 1.62 & 0,23 & 1.79 & 1.54 & 0.24 & - \\
\hline \multicolumn{2}{|r|}{ Total } & 84.57 & 84.11 & 36.49 & 22.80 & 97.70 & 60.93 & 19.95 \\
\hline
\end{tabular}

\subsection{Energy Embodied in Food}

Mass balance of the Italian FSC for the year 2011 for the 13 most important vegetal and animal product types is reported in Table $1[73,74]$. Soybeans were considered as a separate category, since FAO includes them among oil crops, despite the fact that they are pulses and their main byproduct is soy cake for animal feed. Meat included also animal fats and offal, while milk included also butter and cheese. Domestic supply (S) was obtained as the result of Production $(P)$ plus Imports $(I)-$ Exports $(O)$; slight differences between $S$ and $P+I-O$ may derive from stock variations.

Supply is split in three different destinations: food $(F o)$, feed $(F e)$ and other uses, which include employment as seeds, biofuels, industry feedstock and waste. Food is intended as the fraction of agricultural and livestock production dedicated to human consumption, both as raw or processed products. In order to limit the number of product types, in the case of oilseeds and sugar crops this voice includes also transformed food: $1.88 \mathrm{Mt}$ of "oilseeds food" is constituted by $0.18 \mathrm{Mt}$ of oilseeds and 1.70 Mt of oils, while 1.77 Mt of "sugar crops food" is just refined sugar.

Feed is the sum of two different contributions: $F e_{A}$ is the feed for the meat, milk, egg and fish (aquaculture) human FSC, while $F e_{B}$ is the feed for pets and horses for race and entertainment. Pet feed (dogs, cats, birds and aquarium fishes) amounts to $0.5 \mathrm{Mt}$ per year, that is approximately $3 \%$ of total feed [75]. In the period 2009-2014, the average number of horses that were not part of human FSC was 273,000 , approximately $2 \%$ of the total biomass of Italian livestock [76]. Assuming that feed consumption is proportional to the masses of different animals, horses should consume $2 \%$ of the total feed. Therefore, $F e_{B}$ is $5 \%$ of $F e$, and $F e_{A}$ represents $95 \%$ of the feed column of Table $1 . F e$ and $F e_{A}$ are reported in Figure A2 of Appendix for the period considered.

For each of the items in Table 1, feed derived from national production was assumed to be proportional to the ratio of production to total supply; the remainder was imported feed:

$$
F e_{A-n}=\sum_{j=1}^{13} F e_{A-n, j}=\sum_{j=1}^{13} F e_{A, j} \frac{P_{j}}{S_{j}}, F e_{A-i}=\sum_{j=1}^{13} F e_{A-i, j}=\sum_{j=1}^{13} F e_{A, j}\left(1-\frac{P_{j}}{S_{j}}\right)
$$

the national quota of feed was $56 \% \pm 3 \%$ in the $2000-2013$ period (see Figure A2 of the Appendix).

Industrially processed Feed $F e_{\text {proc }}$ is produced with both national and imported products; its amount in the period considered is also reported in Figure A2 [77].

Energy embodied per unit of mass of different food products was calculated according to the following procedure.

Average specific energy at farm level was defined as the ratio of energy use in agriculture and total vegetal and animal production $P$ :

$$
e_{\text {farm }}=\frac{E_{\text {farm }}}{P}
$$

The specific amount of energy required for food processing was defined as: 


$$
e_{\text {proc }}=\frac{E_{\text {proc }}}{M_{\text {proc }}}
$$

where $M_{\text {proc }}$ is the actual mass of food products that underwent a transformation in the food industry; $M_{\text {proc }}$ was determined according to the following formula:

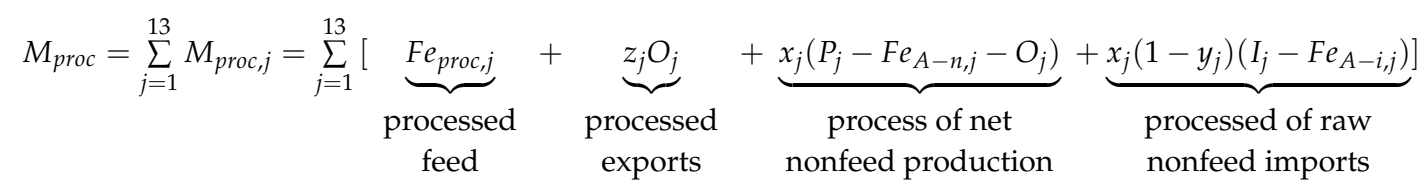

where for each commodity $j$ reported in Table $1(j=1,2, \ldots, 13), x_{j}, y_{j}$ and $z_{j}$ are the percent of processed food in national production, imports and exports, respectively (see flowchart in Figure 1).

Values of $x_{j}, y_{j}$ and $z_{j}$ are reported in Table 2 for all product types. Sources for $x_{j}$ are given in the table, while values of $y_{j}$ and $z_{j}$ were obtained from an elaboration of FAOSTAT trade data [78] and the FAO fishery dataset for fish [79]; in both cases the reported values shows averages and standard deviation for the 2000-2014 period. Equation (5) is the sum of four contributions:

- $\quad$ Processed feed, $F e_{\text {proc-j }}$, that is approximately $70 \%$ of feed used in the human FSC $F E_{A}$ (see Figure A2).

- $\quad$ Processed exports $z_{j} O_{j}$.

- $\quad$ Process quote $x_{j}$ of the net production for direct human consumption (that is production minus exports and national feed).

- $\quad$ Process quote $x_{j}$ of imported food for direct human consumption that was not already processed abroad $\left(1-y_{j}\right)\left(I_{j}-F e_{A-I, j}\right)$.

Table 2. Percent of processed food in Italy $\left(x_{j}\right.$ and $\left.z_{j}\right)$ or abroad $\left(y_{j}\right)$ for different product types. In row 10 the processed percent of exported and imported meat is less than $100 \%$, because the remaining part (unprocessed meat) is constituted by live animals.

\begin{tabular}{cccccl}
\hline \multirow{2}{*}{$j$} & Product Type & \multicolumn{3}{c}{ Processed Percent } & \multicolumn{1}{c}{ Sources for $x_{j}$} \\
\cline { 3 - 5 } & & Internal $\left(x_{j}\right)$ & Imported $\left(y_{j}\right)$ & Exported $\left(z_{j}\right)$ & \\
\hline 1 & Cereals & $92.7 \% \pm 1.0 \%$ & $6.1 \% \pm 1.0 \%$ & $87.3 \% \pm 4.8 \%$ & $\begin{array}{l}\text { All cereals except rice, dried at } \\
\text { farms }(3.3 \%)\end{array}$ \\
\hline 2 & Tubers & $14.2 \% \pm 2.3 \%$ & $28.8 \% \pm 2.8 \%$ & $3.7 \% \pm 1.1 \%$ & {$[80]$} \\
\hline 3 & Pulses & $87.6 \% \pm 7.8 \%$ & $81.2 \% \pm 4.2 \%$ & $58.4 \% \pm 4.9 \%$ & {$[81,82]$} \\
\hline 4 & Soybeans & $100 \%$ & $65.5 \% \pm 5.5 \%$ & $84.2 \% \pm 9.8 \%$ & All soy is processed for oil and meals \\
\hline 5 & Oilseeds & $92.2 \% \pm 2.1 \%$ & $84.6 \% \pm 1.9 \%$ & $97.5 \% \pm 1.2 \%$ & [76] \\
\hline 6 & Sugar crops & $100 \%$ & $100.0 \%$ & $100.0 \%$ & All sugar is processed from sugar beet \\
\hline 7 & Vegetables & $27.5 \% \pm 2.7 \%$ & $55.3 \% \pm 3.6 \%$ & $71.2 \% \pm 1.7 \%$ & [81-83] \\
\hline 8 & Fruits & $12.2 \% \pm 1.3 \%$ & $20.8 \% \pm 2.0 \%$ & $21.5 \% \pm 1.2 \%$ & [81-84] \\
\hline 9 & Wine, Beer & $100 \%$ & $100.0 \%$ & $100.0 \%$ & All beverages are processed \\
\hline 10 & Meat & $100 \%$ & $74.0 \% \pm 3.5 \%$ & $91.6 \% \pm 1.5 \%$ & $\begin{array}{l}\text { All meat processed in } \\
\text { slaughterhouses }\end{array}$ \\
\hline 11 & Milk & $100 \%$ & $100 \%$ & $\begin{array}{l}\text { All milk is pasteurized or } \\
\text { homogenized }\end{array}$ \\
\hline 12 & Eggs & $34 \%$ & $17.6 \% \pm 9.2 \%$ & $44.2 \% \pm 16 \%$ & [85] \\
\hline 13 & Fish & $92.08 \% \pm 6.6 \%$ & $76.6 \% \pm 1.24 \%$ & $48.2 \% \pm 3.15 \%$ & [79] \\
\hline & Sources: $\mathrm{x}_{j}$ values, see last column; $y_{j}$ and $z_{j}$ values sourced from FAOSTAT [86] and FIGIS [79].
\end{tabular}


The specific input for transportation can be defined in relation to all food moved, that is total production, exports included:

$$
e_{\text {tran }}=\frac{E_{\text {tran }-N}+E_{\text {tran }-E}}{P}
$$

Specific input for distribution is related to the market quote $q$ of modern retailers of the total food (Fo); in $2012 q$ was equal to $72 \%$ [87]:

$$
e_{\text {dist }}=\frac{E_{\text {dist }}}{q F o}
$$

\subsection{Vegetal and Animal Products}

The specific values defined in the previous section are representative for all products in the Italian FSC. Animal products require an additional specific energy input for feed farming, processing and transport, defined as

$$
e_{\text {feed }}=\frac{F e_{A-n} e_{\text {farm }}+F e_{\text {proc }}\left(e_{\text {proc }}+e_{\text {tran }-N}\right)}{P_{\text {anim }}}
$$

where $P_{\text {anim }}$ is the production of animal products, meat, milk, eggs and fish:

$$
P_{\text {anim }}=\sum_{j=10}^{13} P_{j}
$$

The farming energy intensity is related only to the national products used for feed, while the processing intensity is related to industrial prepared feed. Transport was associated to $F e_{\text {proc }}$, because this second quantity contains also the first. This value was added to $e_{\text {farm }}$ to obtain the energy input for animal products. All equations from Equations (3) to (9) were used for all years from 2000 to 2013.

\subsection{Nutritional and Embodied Energy in Food Waste}

Available data for FLW at European level at different stages of the FSC (farming, post-harvest,

\begin{tabular}{|c|c|c|c|c|c|c|}
\hline \multirow{3}{*}{$j$} & \multirow{3}{*}{$\begin{array}{l}\text { Product } \\
\text { Type }\end{array}$} & \multicolumn{4}{|c|}{ FSC Step } & \multirow{3}{*}{$\begin{array}{c}\text { Food Energy } \\
(\mathrm{MJ} / \mathrm{kg})\end{array}$} \\
\hline & & \multicolumn{2}{|c|}{$w_{\text {farm }}$-Farming } & \multirow{2}{*}{$w_{\text {proc }}$-Processing } & \multirow{2}{*}{$w_{d i s t}$-Distribution } & \\
\hline & & $w_{\text {farm } 1}$-on the field & $w_{\text {farm } 2}$-Post-Harvest & & & \\
\hline 1 & Cereals & $2.0 \%$ & $4.0 \%$ & $10.0 \%$ & $2.0 \%$ & 11.03 \\
\hline 2 & Tubers & $20.0 \%$ & $9.0 \%$ & $15.0 \%$ & $7.0 \%$ & 2.64 \\
\hline 3 & Pulses & \multirow{3}{*}{$10.0 \%$} & \multirow{3}{*}{$1.0 \%$} & \multirow{3}{*}{$5.0 \%$} & \multirow{3}{*}{$1.0 \%$} & 14.35 \\
\hline 4 & Soybeans & & & & & 14.41 \\
\hline 5 & Oilseeds & & & & & 6.82 \\
\hline 6 & Sugar crops & $4.2 \%{ }^{a}$ & $2.3 \% \mathrm{~b}$ & - & $1.2 \%{ }^{c}$ & 14.88 \\
\hline 7 & Vegetables & \multirow{2}{*}{$20.0 \%$} & \multirow{2}{*}{$5.0 \%$} & \multirow{2}{*}{$2.0 \%$} & \multirow{2}{*}{$10.0 \%$} & 0.97 \\
\hline 8 & Fruits & & & & & 1.76 \\
\hline 9 & Wine, Beer & - & - & $0.89 \% \mathrm{~d}$ & - & 2.62 \\
\hline 10 & Meat & $3.2 \%$ & $0.7 \%$ & $5.0 \%$ & $4.0 \%$ & 6.71 \\
\hline 11 & Milk & $3.5 \%$ & $0.5 \%$ & $1.2 \%$ & $0.5 \%$ & 1.68 \\
\hline 12 & Eggs & $4 \%$ & - & $0.5 \%$ & $2.0 \%$ & 6.20 \\
\hline 13 & Fish & $9.4 \%$ & $0.5 \%$ & $6.0 \%$ & $9.0 \%$ & 5.89 \\
\hline
\end{tabular}
processing, and distribution) are reported in Table 3 for the same 13 groups of vegetal and animal products listed in Tables 1 and 2.

Table 3. Percentage of food losses and waste at different steps of the FSC. 
It is worth noting, that, according to the methodology developed by Gustavsson et al. [25,88], and as detailed below, all these percentages are related to different totals and cannot simply be summed to obtain a total food waste percentage.

The second column of Table 3 reports the "loss on the field" data that refers to crop left in the fields or to animals died before slaughtering. For each product group $j(j=1,2, \ldots ., 13)$ the percentages $w_{\text {farm } 1}$ were referred to the gross agricultural production $P_{0}$ :

$$
w_{f a r m 1 j}=\frac{P_{0 j}-P_{j}}{P_{0 j}}
$$

Data for $P_{0 j}$ were not available but they were estimated from Equation (10) as:

$$
P_{0 j}=\frac{P_{j}}{1-w_{f a r m 1 j}}
$$

Therefore, absolute waste $W_{1 j}$ was defined as:

$$
W_{\text {farm } 1 j}=w_{f a r m 1 j} P_{0 j}
$$

The second contribution is the post-harvest loss, due to inappropriate storing condition or quality controls. For each commodity, this fraction of post-harvest waste $w_{\text {farm } 2}$ (third column of Table 3) must be related to the total production $P_{J}$; consequently, the absolute amount of FLW at post-harvest was defined as:

$$
W_{\text {farm } 2 j}=w_{\text {farm } 2 j} P_{j}
$$

Gustavsson et al. $[25,88]$ did not include feed values in the computation, considering strictly the direct waste of food. On the contrary, according to the specific approach used in the present work, animal feed was included in the computation of $W_{\text {farm } 2 j}$ because it was an indirect waste of food and energy was already spent to produce it.

The FLW at farm level is the sum of the two contributions in Equations (12) and (13):

$$
W_{f a r m j}=W_{f a r m 1 j}+W_{f a r m 2 j}
$$

For each commodity, the fraction $w_{\text {procj }}$ of FLW during processing (fourth column of Table 3) must be related to the corresponding $j$-term forming the total quantity of processed food $M_{\text {proc }}$ (see Equation (5)), with the exception of processed feed, since it is assumed that the processing waste percentage of Table 3 applies only to food; the absolute amount of waste was defined as:

$$
W_{\text {procj }}=w_{\text {procj }}\left(M_{\text {proc }-j}-F e_{\text {proc }, j}\right)
$$

For each group, the fraction $w_{\text {distj }}$ of FLW at the distribution level (fifth column of Table 3 ) is related to all food $\mathrm{Fo}_{j}$ :

$$
W_{d i s t j}=w_{d i s t j} F o_{j}
$$

The Food Energy Waste (FEW) was computed using FAO data on food energy values for all the above mentioned food categories [86]. The Embodied Energy Waste (EEW) was computed assuming that embodied energy builds up along the chain, so the latter the waste occurs, the greater the energy waste, as detailed in Table 4. Energy input at the farm level for animal products must also account for feed. At the distribution level, energy for processing is applied only to the fraction $x$ of transformed products. 
Table 4. Scheme for computing energy embodied in food waste. Source: Authors' elaboration.

\begin{tabular}{cc}
\hline Waste Occurs at: & Energy Wasted for Unit Mass of Food Waste \\
\hline Farm & $e_{f a r m}\left(+e_{f e e d}\right.$ for animal products $)$ \\
Processing & $e_{f a r m}+e_{\text {tran }}+e_{\text {proc }}\left(+e_{f e e d}\right.$ for animal products $)$ \\
Distribution & $e_{f a r m}+e_{t r a n}+x e_{\text {proc }}+e_{\text {dist }}\left(+e_{f e e d}\right.$ for animal products $)$ \\
\hline
\end{tabular}

\section{Results}

\subsection{Total Energy Use in the FSC}

Total energy utilization of Italian FSC peaked in year 2002 to almost 1000 PJ (see Figure 2) and then steadily declined in the following decade to reach $758 \mathrm{PJ}$ in 2014 ( $-23.3 \%$ with respect to 2002 maximum), with the greatest year-to-year variation between 2008 and $2009(-7.2 \%)$ in conjunction with the oil price shock [93].

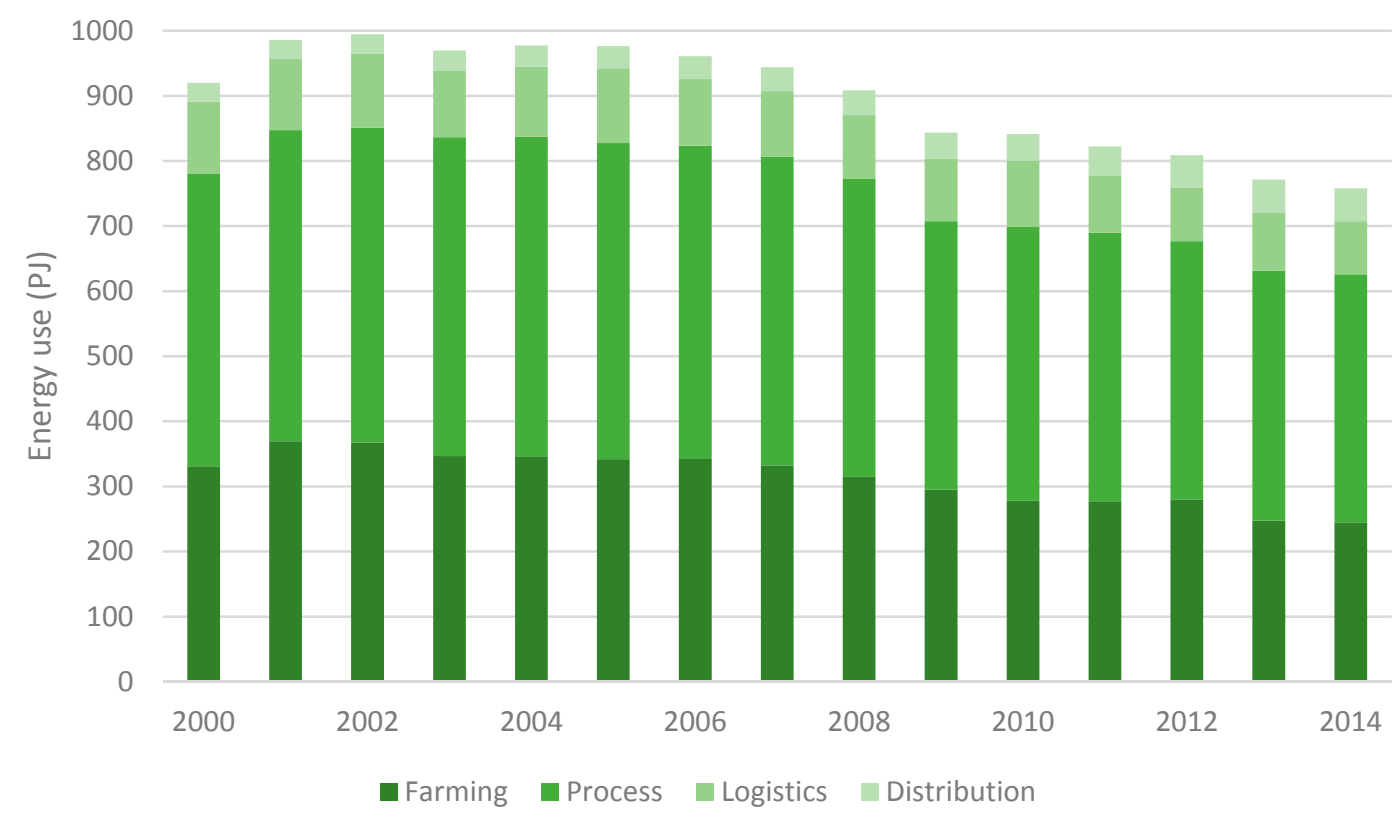

Figure 2. Total Energy use in the Italian food chain, 2000-2014.

The farming sector presented a 31\% downturn between 2002 and 2014. Within farming, the strongest decrease occurred in new machinery $(-55 \%)$, fertilizers $(-40 \%)$ and pesticides $(-43 \%)$ use.

During the same time period, the food process sector registered $-21.6 \%$, with the greatest decrease in direct energy use $(-35 \%)$, while energy embodied in packaging changed only slightly $(-11.2 \%)$. Logistics contracted by $22 \%$, with the greatest reduction in exports $(-55 \%)$. The distribution sector was in countertrend, because it presented an increase in energy use greater than $60 \%$ in the same period.

In the whole period under exam, energy utilized in the FSC decreased faster than total energy use $(-14 \%)$, so the incidence of the FSC on the total energy budget declined from $12.5 \%$ to $11 \%$ of the national energy budget [35]. This range of variation (11\%-13\%) can be considered consistent with previous estimates provided by Campiotti et al. [34], and Sanfilippo and Ruggeri [94], that are slightly higher (16\% and 15\%-19\%, respectively) as they include also the consumption segment. The reduction in energy employment is mainly linked to a decrease in the total production, which contracted from 100 to $78 \mathrm{Mt}$ between 2000 and 2014, while energy intensity has remained almost constant (see Figure 3 below). 


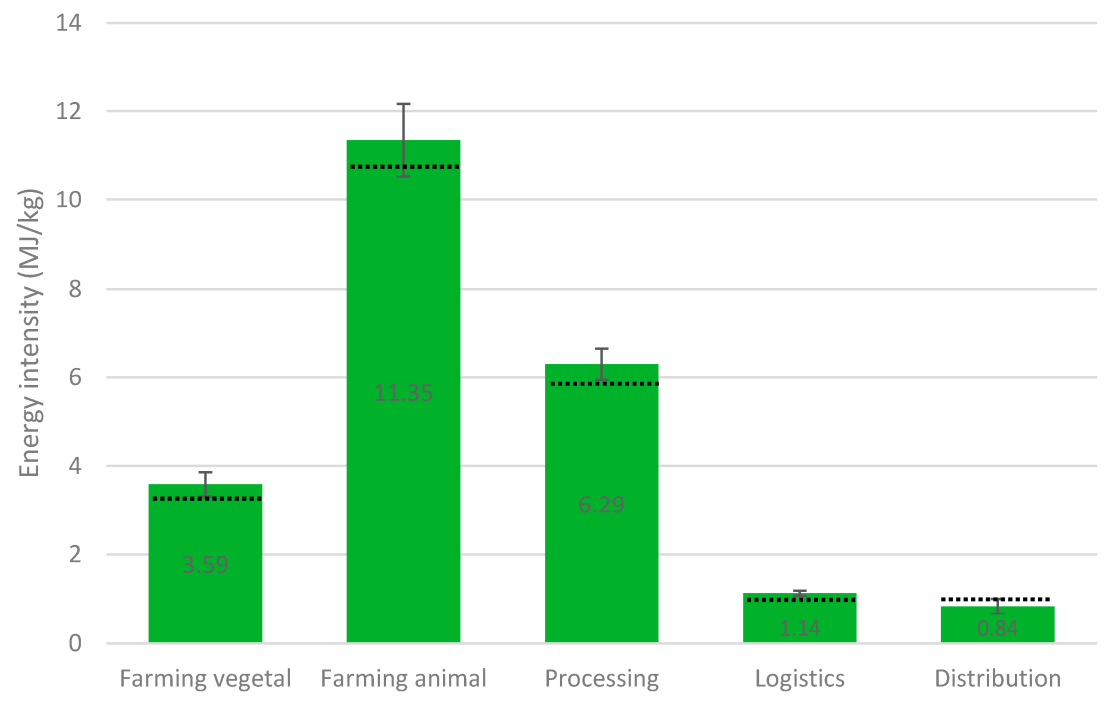

Figure 3. Average energy intensity for the different steps of the food chain, 2000-2011 (green bars), standard deviation (error bars) and energy intensity for the year 2011 (dotted lines).

In the year 2011, the most relevant contributions to energy use derived from the process sector (packaging included), with more than $410 \mathrm{PJ}$, or roughly half of the total, while packaging alone weighs $31 \%$. Farming contributes with $277 \mathrm{PJ}$, that is more than one third of the total, with almost equal contributions from direct and indirect inputs, while transportation counted for $10.5 \%$ and retail for $5.5 \%$.

These relative figures are hardly comparable to other studies [14,34,94], as agricultural indirect energy inputs were not always accounted for, and food consumption was usually included. Furthermore, the study did not include the recycling of packaging materials, which can provide significant energy savings with respect to disposal in landfill: $20 \%$ for glass, $60 \%$ for plastics and $80 \%$ and more for aluminum and steel [95]. Notably, more than half of the package impact derived from plastic polymers.

Since the total nutritional energy output of the FSC in 2011 was equivalent to 323 PJ [86], the average input/output ratio can be estimated in 2.54, that is $2.54 \mathrm{MJ}$ of primary energy were required to obtain $1 \mathrm{MJ}$ of food before consumption. This figure seems lower than data from other countries, such as UK [96], probably because of the diversity in terms of intensity of production systems, energy use, role or renewable sources, share of imported commodities, and average national diets.

Figure 3 shows the average energy intensity for the different segments of the Italian FSC in the 2000-2013 period; the small values of standard deviations (indicated by error bars in Figure 3) denote little change in energy intensity during the period. Dotted lines show the energy intensity levels of 2011, used in Section 3.2 for the determination of the energy embodied in food waste.

At the farming level $3.6 \pm 0.3 \mathrm{MJ}$ were required per $\mathrm{kg}$ of vegetal product, while every $\mathrm{kg}$ of animal products requires an additional $7.8 \pm 0.6 \mathrm{MJ}$ of feed energy (Equation (8)), for a total footprint of $11.4 \pm 0.8 \mathrm{MJ}$ (for year 2011, the intensities of vegetal and animal farming were 3.28 and $10.79 \mathrm{MJ} / \mathrm{kg}$, respectively).

Processing contributed for $6.3 \pm 0.4 \mathrm{MJ} / \mathrm{kg}$ (5.89 in 2011), while the impact of logistics and distribution is significantly smaller, $1.14 \pm 0.05 \mathrm{MJ} / \mathrm{kg}(1.03$ in 2011) and $0.84 \pm 0.2 \mathrm{MJ} / \mathrm{kg}(1.04$ in 2011), respectively.

On average, fresh vegetal products have an intensity of $5.7 \pm 0.5 \mathrm{MJ} / \mathrm{kg}$, while processed vegetal are double, $12.0 \pm 0.8 \mathrm{MJ} / \mathrm{kg}$. Almost all animal products are processed and require an energy intensity of $19.1 \pm 1.2 \mathrm{MJ} / \mathrm{kg}$.

As can be seen from Table 5, these values are comparable with energy inputs determined for single raw or processed vegetal products, and with a weighted average of animal products $[97,98]$, 
for animal products the average is weighted according to the Italian production). The distribution segment was not included, since it is not considered by the environmental product declarations.

Processed products reported in Table 5 are packed in paper, plastics or steel and reflect the average process energy intensity outlined in this study. By contrast, products contained in glass have an overall significant higher energy intensity (14-20 MJ), owing to the greater mass of glass [99].

Table 5. Comparison between results on FSC energy intensity from the present work (without the distribution segment) and selected data from Italian Environmental Product Declarations.

\begin{tabular}{ccc}
\hline & Products & Energy Intensity (MJ/kg) \\
\hline \multirow{2}{*}{ Raw vegetal products } & Apples & 4.7 \\
& Potato & 3.57 \\
& This work & $5.1 \pm 0.3$ \\
\hline \multirow{2}{*}{ Processed vegetal products } & Industrial bread & 10.08 \\
& Pasta & 9.84 \\
& Canned beans & 12.91 \\
& Canned tomato & 12.13 \\
Processed animal products & Packed salad & 16.7 \\
& This work & $11.4 \pm 0.7$ \\
\hline & Average of meat (bovine-swine), & 16.3 \\
\hline
\end{tabular}

Source: Authors' elaboration on data from Carlsson-Kanyama [97], Environdec [98] and Pagani et al. [100,101].

\subsection{The Double Energy Waste}

Using FAO estimates for Europe $[25,88]$, it was possible to estimate FLW related to Italian FSC (Table 6). In fact, no reliable data with the same level of specification in food categories were available for the Italian territory. Thus it was deemed more conservative to rely on European averages. The determination was performed for the year 2011, since no more recent data are available from FAO. Food mass waste (FMW) amounted to $17.9 \mathrm{Mt}$, so $17.3 \%$ of the total food supply $S=P+I$ - $O$ of $103 \mathrm{Mt}$ [86] did not reach consumption. Taking into account that Italy has slightly more than sixty million inhabitants, per capita FLW were therefore equal to roughly $301 \mathrm{~kg} /$ year, which is consistently higher than the figure provided by Gustavsson et al. [25] for EU Countries, due the inclusion of feed waste and despite the exclusion of consumption waste. The greatest waste occurred for fruit and vegetables (two thirds of the total), followed by cereals and tubers. Most waste occurred at agricultural level.

From an energy point of view, this value represents a double waste, since both the nutritional energy contained in food (FEW) and the embodied energy (EEW) used at the different steps of the FSC are discarded. Absolute results of this analysis are reported in Table 6 for the different steps of the FSC, while Figure 4 shows the percent incidence of the different product types on FMW, FEW, and EEW. Detailed results, both for product type and FSC steps are reported in the Tables A3 and A4 of the Appendix.

Table 6. Food Mass Waste (FMW), Food Energy Waste (FEW) and Embodied Energy Waste (EEW) for the different steps of the FSC, year 2011.

\begin{tabular}{ccccc}
\hline Waste Type & Farming & Processing & Distribution & Total \\
\hline Food Mass Waste (Mt) & 12.75 & 2.47 & 2.64 & 17.87 \\
Food Energy Waste (PJ) & 37.04 & 21.35 & 8.49 & 66.89 \\
Embodied Energy Waste (PJ) & 47.42 & 28.43 & 24.21 & 100.07 \\
\hline
\end{tabular}

Source: Adapted by the authors based on Gustavsson $[25,88]$. 


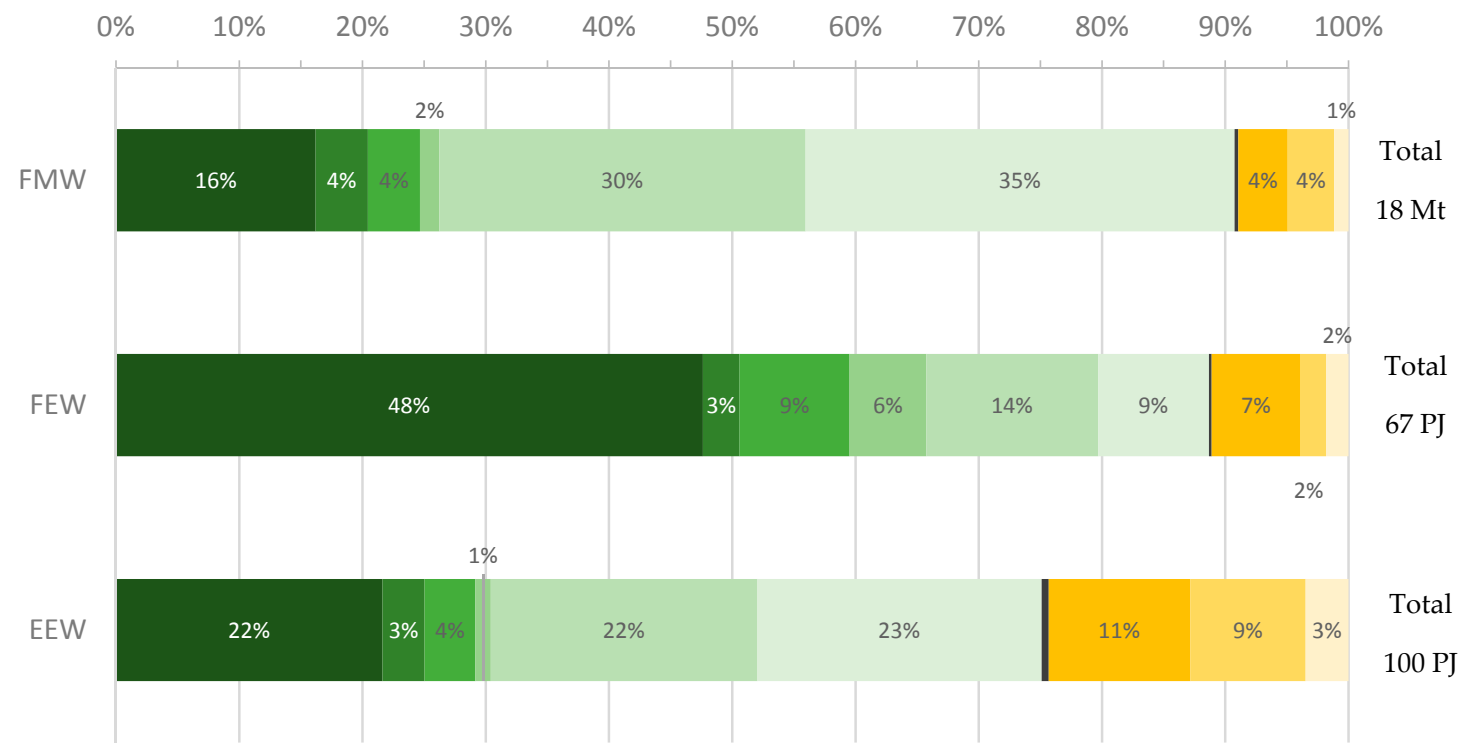

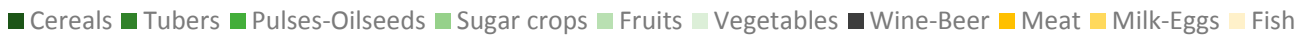

Figure 4. Comparative composition of Food Mass Waste (FMW), Food Energy Waste (FEW) and Embodied Energy Waste (EEW), year 2011.

In 2011, Italian FEW reached 66.89 PJ, equivalent to $15 \%$ of the total potential energy output of production $P_{0}(444 \mathrm{PJ})$ and $21.9 \%$ of the energy output of all food. Preventing this waste would have significant consequences on FSC efficiency with a $13.6 \%$ decrease in the average input/output ratio, due to a higher output.

Despite the large difference in terms of FMW, cereals have a higher relevance than fruits and vegetables, when nutritional energy content is taken into account. Similarly, the impact of oilseed, pulses and meat on FEW is much larger. The inclusion of food nutritional properties in the characterization of food waste could represent a way to prioritize the prevention or recovery of some product categories. However, optimal strategies cannot rely solely on the calorific content, as several other nutritional aspects should be taken into account.

EEW was equal to $100 \mathrm{PJ}$, which was the $12.2 \%$ of the energy spent in the FSC, and $1.3 \%$ of the total final use. It is important to emphasize how this estimate is significantly lower than the average value calculated for the US [13] most probably due to the exclusion of the energy embodied in the consumption segment. Notwithstanding, the energy wasted through discarded food is roughly $15 \%$ greater than the energy demand by food transport and equivalent to 2.5 times the energy required by the distribution segment. Compared to other energy policy measures, EEW savings correspond to the $26.6 \%$ of total Italian production from all the renewable energy sources [102]. However, it must be noted that further food waste data specifically related to Italy are needed to draft definitive conclusions.

Different level of EEW savings would be achievable basing on the different product categories. In fact, owing to a higher energy footprint, animal derived food waste (meat, milk, and fish) is responsible for a much more than proportional energy loss, weighing only $9 \%$ in terms of mass, but $21 \%$ in terms of wasted energy.

\subsection{Sensitivity Analysis}

Variations in data reported in the previous section were related to year-to-year changes in energy use or food production. All direct energy use data may be considered reliable, as they were sourced from official statistics, while indirect inputs rely on energy intensities. Each of the values used for 
the parameters was considered by the authors as the best choice at the moment of publication, but nevertheless each of them is characterized by a degree of uncertainty. It is therefore important to define the sensitivity of the results to a change in energy intensity parameters. Results are referred to data of year 2011.

\subsubsection{Farming}

Taking into account energy intensity values reported by several authors, a $\pm 17 \%$ variation was considered with respect to the average fertilizer energy intensity assumed in Section 2.1.1.

For pesticides, differences among various data can be estimated as $\pm 100 \mathrm{MJ} / \mathrm{kg}$ for insecticides, $\pm 70 \mathrm{MJ} / \mathrm{kg}$ for herbicides and \pm 110 for fungicides.

Machinery energy intensity presents the largest variance, due to the limited availability of data. Estimation may vary from $90 \mathrm{MJ} / \mathrm{kg}$, in the case of perfect operations with no maintenance, to $180 \mathrm{MJ} / \mathrm{kg}$ [38]. However, the impact of machinery energy on the overall agriculture input is so small that its indetermination does not lead to any significant difference.

Energy for farming can thus vary of \pm 25 PJ (see Figure 5).

\subsubsection{Processing}

Energy intensities were defined more precisely for packages and variations are smaller, as detailed below:

- $\quad$ Paper: from 7.7 to $8.9 \mathrm{MJ} / \mathrm{kg}$ [103].

- $\quad$ Glass: from 12.5 to $20 \mathrm{M} / \mathrm{kg}$ [104,105].

- $\quad$ Aluminum: from 145 to $165 \mathrm{MJ} / \mathrm{kg}[105,106]$.

- $\quad$ Steel: from 17.5 to $27.5[105,107]$.

- Plastics: from 75.3 to $79.6[55,56,108-112]$.

- Wood: no significant variation [105].

As a consequence, energy for process may vary of $\pm 21 \mathrm{PJ}$.

\subsubsection{Logistics}

The analysis was performed on road freight that represents more than $97 \%$ of the total energy for logistics. According to International Energy Agency [65], energy intensity for road transport can vary form $1.9 \mathrm{MJ} / \mathrm{t} \cdot \mathrm{km}$ to as much as $6.5 \mathrm{MJ} / \mathrm{t} \cdot \mathrm{km}$. This upper value was taken into account to define the worst possible scenario for transportation. As a result, the energy for logistics may vary between 57 and $189 \mathrm{PJ}$, which is a great variation in relative terms, but not so relevant when compared to the entire FSC.

\subsubsection{Distribution}

Taking into account the values in energy use per square meter $\left(900-1600 \mathrm{MJ} / \mathrm{m}^{2}\right.$ per year) reported by Santi and Elia [72], the overall variation in the distribution sector can change from 33 to 58 PJ.

The results of the analysis are shown in Figure 5 for the total energy use in the FSC. Changes can be significant, mainly for transport energy, due to the larger variation range in intensity. Nevertheless, main findings outlined in the previous section are not significantly altered by these variations. Process remains the most important factor, followed by farming, logistics and distribution. Only in the case of a highly efficient logistics and an inefficient retail, the two sectors have approximately the same relevance. 


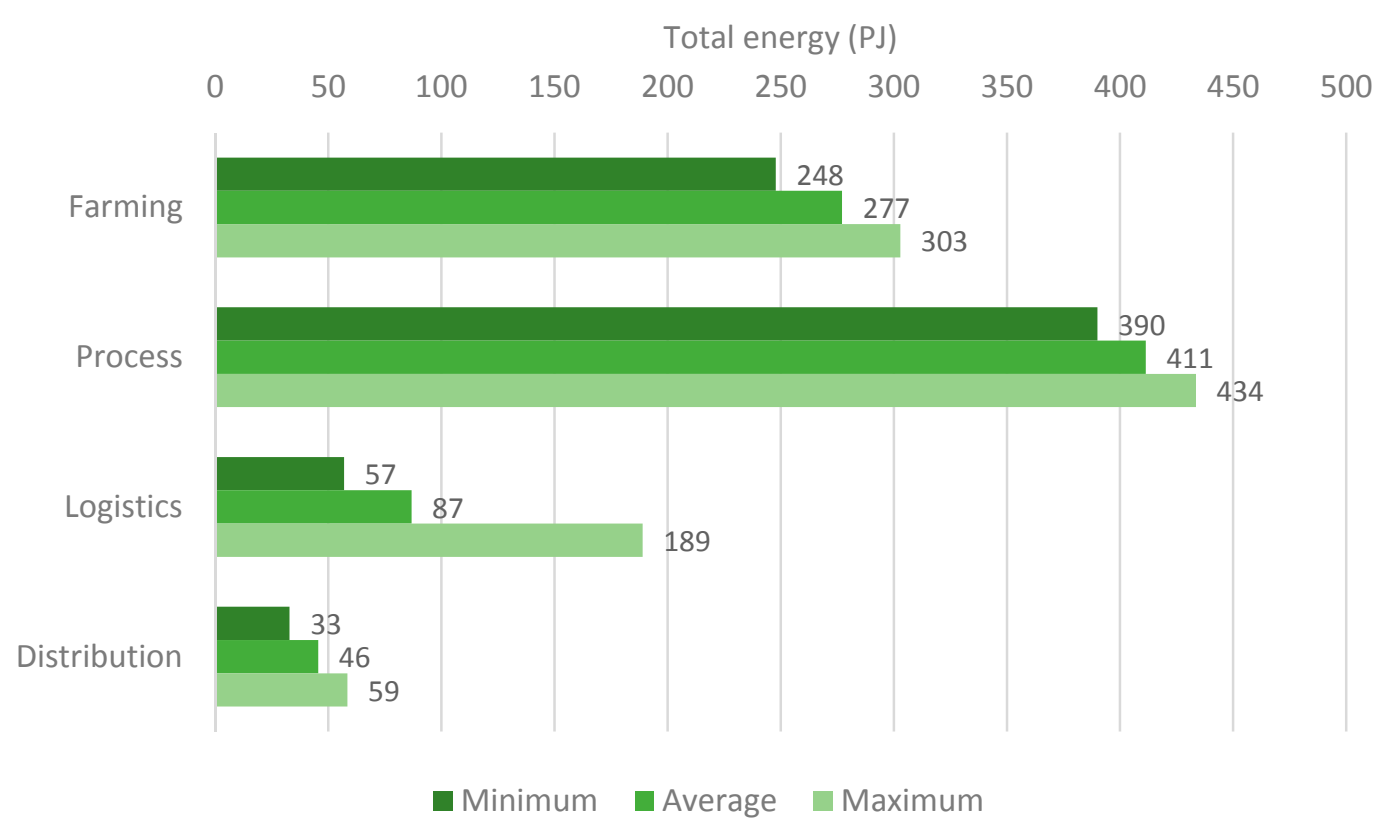

Figure 5. Variations in the total energy inputs of the Italian FSC of year 2011 as a consequence of a variation of the energy intensity parameters, as described in the text.

Figure 6 shows the percent variation of EEW for a change in the energy intensity at the various levels of the FSC. Changes are small for variations in the farming sector $( \pm 5 \%)$, process $( \pm 2 \%)$ and distribution $( \pm 1 \%)$, while are more significant for logistics, ranging from $-2 \%$ to $7.6 \%$; as before, this is due to the high upper limit of the road freight energy intensity (see Section 3.3.3).

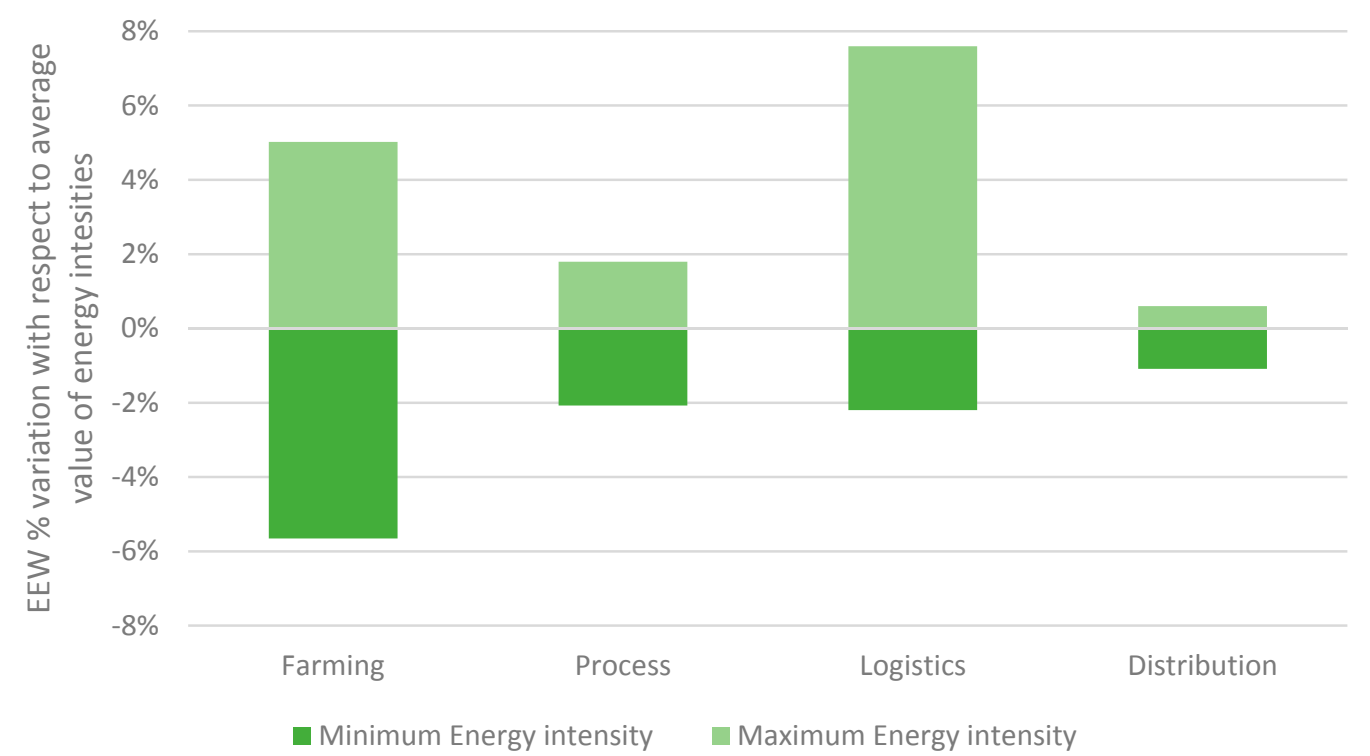

Figure 6. Percent variations in the total Embodied Energy Waste for year 2011 as a consequence of a variation in the Energy intensity parameters, as described from Section 3.3.1 to 3.3.4.

\section{Policy Implications}

The double energy waste concept can provide also relevant insights for policy design. Interventions could regard indirect inputs and their embodied energy, supporting both a quantitative reduction and a qualitative shift towards less energy intensive products and/or practices. For example, 
in the farming sector, potential measures could aim at a reduced use of machinery, promoting low tillage techniques, and a shift towards organic fertilizers and plant products, so to reach a higher energy efficiency without endangering food production levels.

The processing sector should be prioritized as well, so to reduce the use of packaging as much as it does not interfere with food safety, shift from disposable to recyclable/returnable packaging, and introduce as much as possible recycling for all material in local communities. A win-win measure that could augment the sustainability of the food systems would be the replacement of fossil power, heat, and fuels, with renewables counterparts, and in particular bioenergy deriving from byproducts (manure straw, husks). Most of this biomass is or could be easily converted into direct energy input for the food supply chain.

Last but not least, the typology of food consumption should be regarded as an important source of the overall energy bill of FSC, as the composition of the average national diet determines a higher or lower share of energy intensive products. The reduction in the consumption levels of meat is regarded as a crucial strategy not only for its positive public health externalities but also for the potential indirect effect on climate change emissions. A similar outcome could be achieved in terms of energy. However, such a shift toward a more sustainable diet will likely require long term and specific political choices and measures (i.e., investments in food education; changes in regulations and policies related to animal products etc.). Thus, short term policies should also focus on the intensiveness of animal farming and, in particular, on the production and composition of feed: less grain products and more hay and alfalfa would lower the energy footprint.

A strategy combining food waste prevention and recovery could represent another tool for reaching higher energy efficiency in the food system. Current levels of waste are a concrete and avoidable loss, both in nutritional and energy terms. The estimate related to the Italian case showed that meaningful gains could be achieved, with the possibility of a higher food availability level at the same cost, a lower energy bill with the same output, or a combination of both. This major insight suggests that food and energy security priorities could, and should be, coordinated within the same food waste policies, aiming at the sufficient amount of food produced and distributed using the lowest amount of energy. A combination of recovery and prevention of food waste could thus result in a mix of higher food availability with a lower energy $I / O$ ratio, and avoided use of energy, to be consumed for other societal purposes.

Furthermore, policies aimed at food waste prevention should take in due account the "double energy" content of different product categories. For example, beside fruits and vegetables, the recovery of animal derived products should be prioritized basing on both their calorific content and embodied energy, while cereals wasting could be considered more relevant because of the related share of nutritional energy wasted. Similarly, also feed waste prevention should be regarded as a measure to lower embodied energy of feed and, thus, a more sustainable animal production.

\section{Conclusions}

The results of this study showed that the double energy waste concept provides an alternative perspective of the multiple interrelations between energy and food security. The analytical model elaborated provided a preliminary estimation of the intensiveness of food produced and distributed in the national territory. Moreover, it allowed investigating the consequences of the amount of food that did not reach final consumption on the nutritional output and energy use.

The reduction in the total energy use in the Italian food supply chain occurred during the 2000-2014 period is in mainly related to a decrease of the total volumes of production and only in a small proportion to a reduction of energy intensity due to increased efficiency.

The most relevant contributions to energy utilization in the food supply chain derives from processing (packaging included) that covers roughly $50 \%$ of the energy input while farming counts for approximately one third. 
Moreover, in 2011, more than $20 \%$ of the energy output of all food was wasted. Reducing this waste would lead to a significant improvement in the efficiency of the food supply chain, which can be estimated in a $13.6 \%$ decrease in the average input/output ratio.

When nutritional energy content is taken into account, cereals have a higher relevance than fruits and vegetables. Similarly, the impact of oilseed, pulses and meat on Food Energy Waste is much larger than on Food Mass Wasted. The inclusion of food nutritional properties in the characterization of food waste could represent a way to prioritize the prevention or recovery of some product categories. However, optimal strategies cannot rely solely on the calorific content, as several other nutritional aspects should be taken into account.

Embodied Energy Waste represented more than $10 \%$ of the energy spent in the food supply chain, and $1.3 \%$ of the total final energy use. Due to a higher energy footprint, animal derived food waste (meat, milk, and fish) is responsible for a much more than proportional energy loss, weighing only $9 \%$ in terms of mass, but $21 \%$ in terms of wasted energy.

The double energy waste can provide also a relevant framework to design policy interventions aimed at improving the energy efficiency of the food systems stimulating a transition towards less energy intensive products and practices. Future research should address the estimation of energy potential of household food waste recovery and the assessment of the energy balance in the downstream segments of the food supply chain.

Author Contributions: Authors contributed equally to design the research and writing the paper. All authors proofread and approved the final manuscript.

Conflicts of Interest: The authors declare no conflict of interest.

Appendix

Table A1. Lower heating values and refinery efficiencies of fuel used in the food chain.

\begin{tabular}{|c|c|c|c|}
\hline Energy Vector & LHV (MJ/kg) & Refinery Efficiency ( $\eta$ ) & $\begin{array}{l}\text { Equivalence Factor for } \\
\text { Gross Energy }(1 / \eta)\end{array}$ \\
\hline Fuel oil & 41.3 & & \\
\hline Diesel fuel & 42.6 & $92.6 \%$ & 1.08 \\
\hline LPG & 46.0 & & \\
\hline Natural gas & 34.3 & $98.5 \%$ & 1.01 \\
\hline Coal & 30.9 & $95.7 \%$ & 1.04 \\
\hline
\end{tabular}

Table A2. Specific input energy for different packaging materials.

\begin{tabular}{ccc}
\hline Material & Percentage Use for Food A & Energy Input (MJ/kg) \\
\hline Paper & $53.0 \%$ & $8.08^{\mathrm{B}}$ \\
Glass & $89.8 \%$ & $15.61^{\mathrm{C}}$ \\
Aluminum & $76.9 \%$ & $155^{\mathrm{D}}$ \\
Steel & $25 \%$ & $25.2^{\mathrm{E}}$ \\
Wood & $15 \%$ & $44^{\mathrm{F}}$ \\
Plastics (weighted average) & $73.7 \%$ & $77.44^{\mathrm{G}}$ \\
\hline
\end{tabular}

Source: ${ }^{\mathrm{A}}$ [57]; ${ }^{\mathrm{B}}[103] ;{ }^{\mathrm{C}}[104]{ }^{\mathrm{D}}[106] ;{ }^{\mathrm{E}}[107] ;{ }^{\mathrm{F}}[105] ;{ }^{\mathrm{G}}[55,56,108-112]$.


Table A3. Masses of food losses and waste at different steps of the FSC.

\begin{tabular}{cccccc}
\hline & & \multicolumn{3}{c}{ Food Mass Waste (Mt) } \\
\cline { 3 - 5 } $\boldsymbol{n n y y y n}$ & Product Type & Farming & Processing & Distribution & \multirow{2}{*}{ Total } \\
\cline { 3 - 5 } & & $\boldsymbol{W}_{\text {farm }}$ & $\boldsymbol{W}_{\text {proc }}$ & $\boldsymbol{W}_{\text {dist }}$ & \\
\hline 1 & Cereals & 1.15 & 1.55 & 0.19 & 2.89 \\
2 & Tubers & 0.53 & 0.06 & 0.16 & 0.76 \\
3 & Pulses & 0.02 & 0.01 & 0.00 & 0.03 \\
4 & Soybeans & 0.07 & 0.01 & 0.00 & 0.08 \\
5 & Oilseed & 0.43 & 0.17 & 0.04 & 0.64 \\
6 & Sugar crops & 0.24 & 0.00 & 0.04 & 0.28 \\
7 & Vegetables & 5.29 & 0.05 & 0.86 & 6.20 \\
8 & Fruits & 4.29 & 0.13 & 0.88 & 5.30 \\
9 & Wine. beer & 0.00 & 0.06 & 0.00 & 0.06 \\
10 & Meat & 0.20 & 0.27 & 0.25 & 0.71 \\
11 & Milk & 0.46 & 0.13 & 0.08 & 0.67 \\
12 & Eggs & 0.03 & 0.00 & 0.01 & 0.05 \\
13 & Fish & 0.04 & 0.03 & 0.14 & 0.21 \\
& Total & 12.75 & 2.47 & 2.64 & 17.87 \\
\hline
\end{tabular}

Table A4. Food energy waste and embodied energy waste for the Italian food chain.

\begin{tabular}{|c|c|c|c|c|c|c|c|c|c|}
\hline \multirow{2}{*}{$j$} & \multirow{2}{*}{$\begin{array}{c}\text { Product } \\
\text { Type }\end{array}$} & \multicolumn{4}{|c|}{ Food Energy Waste (PJ) } & \multicolumn{4}{|c|}{ Embodied Energy Waste (PJ) } \\
\hline & & Farming & Processing & Distribution & Total & Farming & Processing & Distribution & Total \\
\hline 1 & Cereals & 12.68 & 17.08 & 2.08 & 31.85 & 3.77 & 15.82 & 2.04 & 21.63 \\
\hline 2 & Tubers & 1.40 & 0.17 & 0.43 & 2.00 & 1.74 & 0.64 & 1.05 & 3.43 \\
\hline 3 & Pulses & 0.25 & 0.11 & 0.04 & 0.41 & 0.06 & 0.08 & 0.03 & 0.17 \\
\hline 4 & Soybeans & 0.99 & 0.21 & 0.00 & 1.19 & 0.22 & 0.15 & 0.00 & 0.37 \\
\hline 5 & Oilseed & 2.94 & 1.18 & 0.24 & 4.37 & 1.42 & 1.77 & 0.39 & 3.57 \\
\hline 6 & Sugar crops & 3.53 & 0.00 & 0.63 & 4.16 & 0.78 & 0.00 & 0.48 & 1.26 \\
\hline 7 & Fruits & 7.54 & 0.24 & 1.54 & 9.32 & 14.07 & 1.37 & 6.20 & 21.65 \\
\hline 8 & Vegetables & 5.14 & 0.05 & 0.83 & 6.02 & 17.38 & 0.55 & 5.14 & 23.08 \\
\hline 9 & Wine, beer & 0.00 & 0.15 & 0.00 & 0.15 & 0.00 & 0.58 & 0.00 & 0.58 \\
\hline 10 & Meat & 1.36 & 1.78 & 1.65 & 4.79 & 2.19 & 4.71 & 4.60 & 11.50 \\
\hline 11 & Milk & 0.78 & 0.22 & 0.13 & 1.13 & 4.99 & 2.30 & 1.48 & 8.78 \\
\hline 12 & Eggs & 0.20 & 0.01 & 0.09 & 0.29 & 0.34 & 0.02 & 0.21 & 0.57 \\
\hline 13 & Fish & 0.25 & 0.15 & 0.82 & 1.21 & 0.45 & 0.45 & 2.59 & 3.49 \\
\hline & Total & 37.04 & 21.35 & 8.49 & 66.89 & 47.42 & 28.43 & 24.21 & 100.07 \\
\hline
\end{tabular}

Source: Gustavsson [25] for food waste, [86] for food energy and authors elaboration.

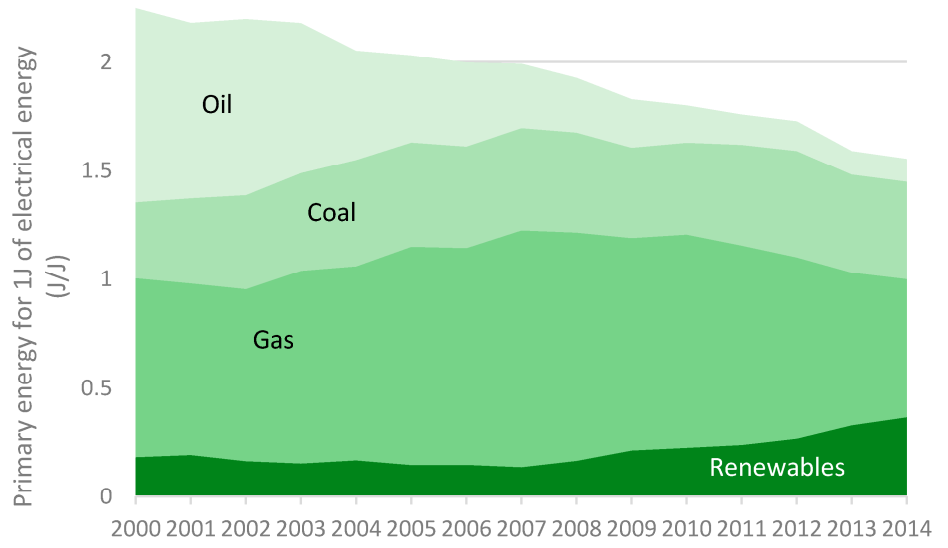

Figure A1. Primary energy equivalent of $1 \mathrm{~J}$ of electrical energy in Italy. Source [35]. 


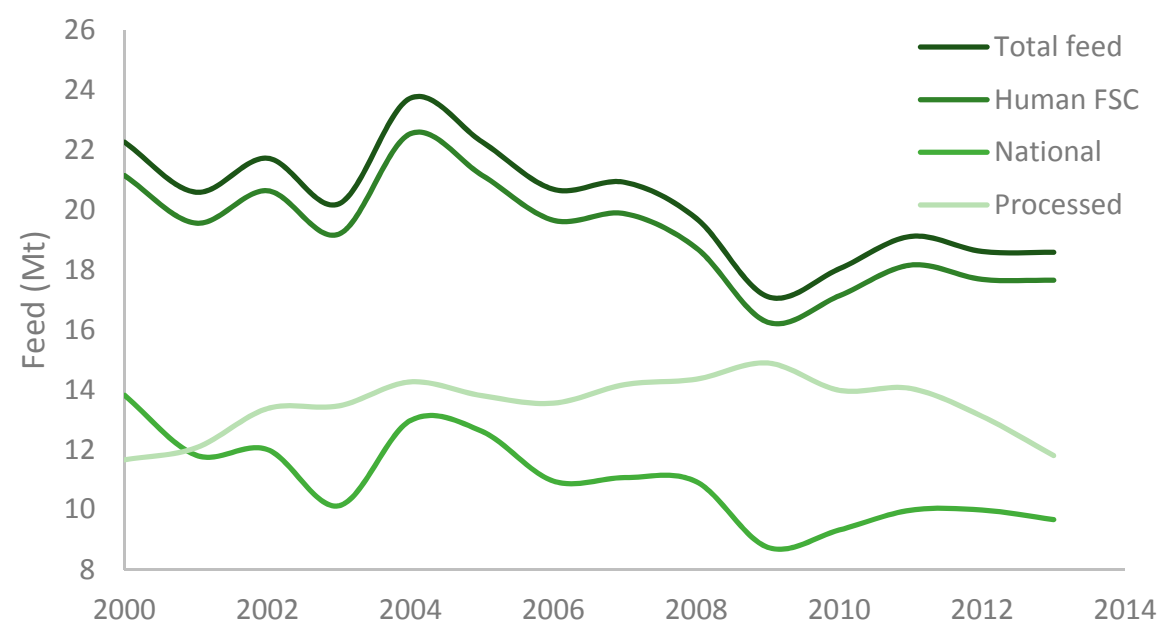

Figure A2. Total feed, feed for use in the human FSC, feed from national products and processed feed.

\section{References}

1. Georgescu-Roegen, N. The Entropy Law and the Economic Process; Harvard University: Cambridge, MA, USA, 1971.

2. Meadows, D.H.; Meadows, D.L.; Randers, J.; Behrens, W.W. The Limits to Growth. A Report for the Club of Rome's Project on the Predicament of Mankind; Universe Books: Washington, DC, USA, 1972.

3. Pieterse, J.N. Development Theory, Handbook of Research on Educational Communications and Technology; Sage Publications: London, UK, 2010.

4. Crutzen, P. Geology of mankind. Nature 2002, 415. [CrossRef] [PubMed]

5. McGlade, C.; Ekins, P. The geographical distribution of fossil fuels unused when limiting global warming to $2{ }^{\circ} \mathrm{C}$. Nature 2015, 517, 187-190. [CrossRef] [PubMed]

6. McMichael, A.J.; Powles, J.W.; Butler, C.D.; Uauy, R. Food, livestock production, energy, climate change, and health. Lancet 2007, 370, 1253-1263. [CrossRef]

7. Steffen, W.; Richardson, K.; Rockström, J.; Cornell, S.E.; Fetzer, I.; Bennett, E.M.; Biggs, R.; Carpenter, S.R.; de Vries, W.; de Wit, C.A.; et al. Planetary boundaries: Guiding human development on a changing planet. Science 2015, 347. [CrossRef] [PubMed]

8. Tilman, D.; Cassman, K.G.; Matson, P.A.; Naylor, R.; Polasky, S. Agricultural sustainability and intensive production practices. Nature 2002, 418, 671-677. [CrossRef] [PubMed]

9. Dorward, A. Agricultural labour productivity, food prices and sustainable development impacts and indicators. Food Policy 2013, 39, 40-50. [CrossRef]

10. Khan, S.; Hanjra, M.A. Footprints of water and energy inputs in food production-Global perspectives. Food Policy 2009, 34, 130-140. [CrossRef]

11. Pimentel, D.; Pimentel, M.H. Food, Energy and Society, 3rd ed.; CRC Press, Taylor and Francis Group: Boca Raton, FL, USA, 2008.

12. IEA (International Energy Agency). IEA Sankey Diagram World Final Consumption. 2013. Available online: http://www.iea.org/Sankey/index.html\#?c=World\&s=Finalconsumption (accessed on 12 May 2016).

13. Cuéllar, A.D.; Webber, M.E. Wasted food, wasted energy: The embedded energy in food waste in the United States. Environ. Sci. Technol. 2010, 44, 6464-6469. [CrossRef] [PubMed]

14. Hendrickson, J. Energy Use in the US Food System: A Summary of Existing Research and Analysis; Center for Integrated Agricultural Systems, University of Wisconsin, 2008. Available online: http:/ /www.cias.wisc. edu/wp-content/uploads/2008/07/energyuse.pdf (accessed on 12 May 2016).

15. Steinfeld, H.; Gerber, P. Livestock's Long Shadow. Environmental Issues and Options; Food and Agricultural Organization: Rome, Italy, 2006. 
16. Smith, P.; Bustamante, M.; Ahammad, H.; Clark, H.; Dong, H.; Elsiddig, E.A.; Haberl, H.; Harper, R.; House, J.; Jafari, M.; et al. Agriculture, Forestry and Other Land Use (AFOLU). In Climate Change 2014: Mitigation of Climate Change; Contribution of Working Group III to the Fifth Assessment Report of the Intergovernmental Panel on Climate Change; Edenhofer, O., Pichs-Madruga, R., Sokona, Y., Farahani, E., Kadner, S., Seyboth, K., Adler, A., Baum, I., Brunner, S., Eickemeier, P., et al., Eds.; Cambridge University Press: Cambridge, UK; New York, NY, USA, 2014. Available online: https://www.ipcc.ch/pdf/assessment-report/ar5/wg3/ipcc_ wg3_ar5_full.pdf (accessed on 12 May 2016).

17. Strazza, C.; Magrassi, F.; Gallo, M.; Del Borghi, A. Life Cycle Assessment from food to food: A case study of circular economy from cruise ships to aquaculture. Sustain. Prod. Consum. 2015, 2, 40-51. [CrossRef]

18. Khoo, H.H.; Lim, T.Z.; Tan, R.B.H. Food waste conversion options in Singapore: Environmental impacts based on an LCA perspective. Sci. Total Environ. 2010, 408, 1367-1373. [CrossRef] [PubMed]

19. Eshel, G.; Martin, P. Diet, energy, and global warming. Earth Interact. 2006, 10. [CrossRef]

20. Mitchell, D. A Note on Rising Food Prices. 2008. World Bank Policy Research Working Paper Series, 2008. Available online: http:/ / ssrn.com/abstract=1233058 (accessed on 12 May 2016).

21. Trostle, R. Global Agricultural Supply and Demand: Factors Contributing to the Recent Increase in Food Commodity Prices; ERS USDA WRS-0801. Available online: http://www.ers.usda.gov/media/218027/wrs0801_1_.pdf (accessed on 12 May 2016).

22. Heinberg, R.; Bomford, M. The Food E Farming Transition: Toward a Post-Carbon Food System; Post Carbon Institute: Sebastopol, CA, USA, 2009.

23. Bush, R. Food riots: Poverty, power and protest. J. Agrar. Chang. 2010, 10, 119-129. [CrossRef]

24. FAO. The State of Food and Agriculture, 2008; Food and Agriculture Organization: Rome, Italy, 2008.

25. Gustavsson, J.; Cederberg, C.; Sonesson, U.; van Otterdijk, R.; Meybeck, A. Global Food Losses and Food Waste. Extent, Causes and Prevention; Food and Agriculture Organization: Rome, Italy, 2011.

26. Parfitt, J.; Barthel, M.; Macnaughton, S. Food waste within food supply chains: Quantification and potential for change to 2050. Philos. Trans. R. Soc. Lond. Ser. B Biol. Sci. 2010, 365, 3065-3081. [CrossRef] [PubMed]

27. Il Libro Nero dello Spreco in Italia: Il Cibo; Segrè, A.; Falasconi, L., Eds.; Edizioni Ambiente: Milano, Italy, 2011.

28. Stenmarck, A.; Jensen, C.; Quested, T.; Moates, G. Estimates of European Food Waste Levels; IVL Swedish Environmental Research Institute: Stockholm, Sweden, 2016; FUSIONS project; ISBN: 978-91-88319-01-2.

29. Kummu, M.; de Moel, H.; Porkka, M.; Siebert, S.; Varis, O.; Ward, P.J. Lost food, wasted resources: Global food supply chain losses and their impacts on freshwater, cropland, and fertilizer use. Sci. Total Environ. 2012, 438, 477-489. [CrossRef] [PubMed]

30. Buzby, J.C.; Hyman, J. Total and per capita value of food loss in the United States. Food Policy 2012, 37, 561-570. [CrossRef]

31. Il Libro Verde dello Spreco in Italia: L'Energia; Segrè, A.; Vittuari, M., Eds.; Edizioni Ambiente: Milano, Italy, 2012.

32. Song, G.; Li, M.; Semakula, H.M.; Zhang, S. Food consumption and waste and the embedded carbon, water and ecological footprints of households in China. Sci. Total Environ. 2015, 529, 191-197. [CrossRef] [PubMed]

33. Grizzetti, B.; Pretato, U.; Lassaletta, L.; Billen, G.; Garnier, J. The contribution of food waste to global and European nitrogen pollution. Environ. Sci. Policy 2013, 33, 186-195. [CrossRef]

34. Campiotti, C.; Viola, C.; Scoccianti, M.; Giagnacovo, G.; Lucerti, G.; Alonzo, G. Le Filiere del Sistema Agricolo per l'Energia e l'Efficienza Energetica. Report RT/2011/11/ENEA Rome. 2011. Available online: http:/ / titano.sede.enea.it/Stampa/Files/cs2011/rapportotecnicocampiotti.pdf (accessed on 12 May 2016).

35. MSE-Ministero dello Sviluppo Economico, Dipartimento per l'Energia. Bilancio Energetico Nazionale, Years from 2000 to 2014. Available online: http://dgerm.sviluppoeconomico.gov.it/dgerm/ben.asp (accessed on 12 May 2016).

36. Giampietro, M. Energy use in agriculture. In Encyclopedia of Life Sciences; 2003; Available online: http: / / onlinelibrary.wiley.com/doi/10.1038/npg.els.0003294/full (accessed on 12 May 2016). [CrossRef]

37. Stout, B.A. Handbook of Energy for World Agriculture; Elsevier: New York, NY, USA, 1991.

38. Mikkola, H.J.; Ahokas, J. Indirect energy input of agricultural machinery in bioenergy production. Renew. Energy 2010, 35, 23-28. [CrossRef]

39. Federunacoma (Federazione Nazionale Costruttori Macchine per l'Agricoltura). Documenti e Dati Statistici. Immatricolazioni. 2014. Available online: http://www.federunacoma.it/it/informati/ind_immatricolazioni. php (accessed on 12 May 2016). 
40. Lazzari, M. MaccAgri.soft. Database di Macchine Agricole con Software per il Calcolo dei Costi di Esercizio, Dip. Scienze e Tecnologie Veterinarie, Univ Milano. 2010. Available online: http://slideplayer.it/slide/ 571349 / (accessed on 12 May 2016).

41. FAOSTAT. Resources, Fertilizers. 2016. Available online: http://faostat3.fao.org/faostat-gateway/go/to/ download/R/RF/E (accessed on 12 May 2016).

42. ISTAT (Istituto Centrale di Statistica). Fertilizzanti. 2013. Available online: http://www.istat.it/it/archivio/ fertilizzanti (accessed on 12 May 2016).

43. Williams, A.G.; Audsley, E.; Sandars, D.L. Determining the Environmental Burdens and Resource Use in the Production of Agricultural and Horticultural Commodities; Main Report; Defra Research Project IS0205; Cranfield University and Defra: Bedford, UK, 2006.

44. Mortimer, N.D.; Cormack, P.; Elsayed, M.A.; Horne, R.E. Evaluation of the Comparative Energy, Global Warming and Socio-Economic Costs and Benefits of Biodiesel; Final Report for the Department for Environment, Food and Rural Affairs, Contract Reference (CSA 5982/NF0422, 20/1); Defra: London, UK, 2003.

45. Ramirez, C.A.; Worrel, E. Feeding fossil fuels to the soil: An analysis of energy embedded and technological learning in the fertilizer industry. Resour. Conserv. Recycl. 2006, 46, 75-93. [CrossRef]

46. Kool, A.; Marinussen, M.; Blonk, H. LCI Data for the Calculation Tool Feedprint for Greenhouse Gas Emissions of Feed Production and Utilization, Blonk Consultants. 2012. Available online: http: //blonkconsultants.nl/upload/pdf/PDV\%20rapporten/fertilizer_production\%20D03.pdf (accessed on 12 May 2016).

47. Hasler, K.; Broring, S.; Omta, S.W.F.; Olfs, H.W. Life cycle assessment (LCA) of different fertilizer product types. Eur. J. Agron. 2015, 69, 41-51. [CrossRef]

48. FAOSTAT. Resources, Pesticides. 2016. Available online: http://faostat3.fao.org/faostat-gateway/go/to/ download/R/RP/E (accessed on 12 May 2016).

49. Helsel, Z.R. Energy and Alternatives for Fertilizers and Pesticide Use. In Energy in Farm Production; Fluck, R.C., Ed.; Energy in World Agriculture; Elsevier: Amsterdam, The Netherlands, 1992.

50. Helsel, Z.R. Energy in Pesticide Production and Use. In Encyclopedia of Pest Management; Taylor \& Francis: London, UK, 2006; pp. 1-4.

51. Green, M.B. Energy in pesticide manufacture, distribution, and use. In Energy in Plant Nutrition and Pest Control, Energy in World Agriculture; Helsel, Z.R., Ed.; Elsevier: Amsterdam, The Netherlands, 1987; Volume 2, pp. 165-177.

52. West, T.O.; Marland, G. A synthesis of carbon sequestration, carbon emissions, and net carbon flux in agriculture: Comparing tillage practices in the United States. Agric. Ecosyst. Environ. 2002, 91, 217-232. [CrossRef]

53. Audsley, E.; Stacey, K.; Parsons, D.J.; Williams, A.G. Estimation of the Greenhouse Gas Emissions from Agricultural Pesticide Manufacture and Use. Cranfield University. 2009. Available online: https:/ /dspace.lib.cranfield.ac.uk/bitstream/1826/3913/1/Estimation_of_the_greenhouse_gas_ emissions_from_agricultural_pesticide_manufacture_and_use-2009.pdf (accessed on 12 May 2016).

54. Scarascia-Mugnozza, G.; Sica, C.; Russo, G. Plastics materials in European agriculture: Actual use and prespectives. J. Agric. Eng. 2011, 3, 15-28. [CrossRef]

55. Plastics Europe. Environmental Product Declaration of the European Plastics Manufacturers. High-Density Polyethylene (HDPE), Low-Density Polyethylene (LDPE), Linear Low-Density Polyethylene (LLDPE). 2014. Available online: http://www.plasticseurope.org/plasticssustainability/eco-profiles/browse-by-list.aspx (accessed on 12 May 2016).

56. Plastics Europe. Environmental Product Declaration of the European Plastics Manufacturers. Polypropylene (PP). 2014. Available online: http://www.plasticseurope.org/plasticssustainability/eco-profiles/browseby-list.aspx (accessed on 12 May 2016).

57. Iascone, B.; Iascone, P.; Aldrigo, D. Imballaggio in Cifre 2011. Consuntivo Generale 2010 dell'Industria Italiana dell'Imballaggio. Istituto Italiano di Imballaggio. 2011. Available online: http://nicolebattilani. altervista.org/alterpages/files/ImballaggioinCifre2011.pdf (accessed on 12 May 2016).

58. Istituto Italiano di Imballaggio. L'Industria Italiana dell'Imballaggio. 2013. Available online: http://www. istitutoimballaggio.it/wp-content/uploads/2011/10/Generale-20131.pdf (accessed on 12 May 2016).

59. Eurostat. Packaging Waste Statistics. 2013. Available online: http://ec.europa.eu/eurostat/statisticsexplained/index.php/Packaging_waste_statistics (accessed on 12 May 2016). 
60. Eurostat. Annual Road Freight Transport by Distance Class with Breakdown by Type of Goods (1 $000 \mathrm{t}$, Mio Tkm, Mio Veh-km, 1000 BTO), until 2007. Available online: http:/ /appsso.eurostat.ec.europa.eu/nui/show. do?dataset=road_go_ta7dctg\&lang=en (accessed on 12 May 2016).

61. Eurostat. Annual Road Freight Transport by Distance Class with Breakdown by Type of Goods (1 $000 \mathrm{t}$, Mio Tkm, Mio Veh-km, 1000 BTO), from 2008 Onwards. 2012. Available online: http:/ /appsso.eurostat.ec. europa.eu/nui/show.do?dataset=road_go_ta_dctg\&lang=en (accessed on 12 May 2016).

62. Schipper, L.; Scholl, L.; Price, L. Energy use and carbon emissions from freight in 10 industrialized countries: An analysis of trends from 1973 to 1992. Transp. Res. Part D 1997, 2, 55-76. [CrossRef]

63. Weber, C.L.; Matthews, H.S. Food-miles and the relative climate impacts of food choices in the United States. Environ. Sci. Technol. 2008, 42, 3508-3513. [CrossRef] [PubMed]

64. Kamakaté, F.; Schipper, L. Trends in truck freight energy use and carbon emissions in selected OECD countries from 1973 to 2005. Energy Policy 2009, 37, 3743-3751. [CrossRef]

65. IEA, International Energy Agency. Transport, Energy and $\mathrm{CO}_{2}$. Moving towards Sustainability. 2009. Available online: https://www.iea.org/publications/freepublications/publication/transport2009.pdf (accessed on 12 May 2016).

66. Spritmonitor.de. MPG and Cost Calculator and Tracker. 2016. Available online: http://www.spritmonitor. de/en/ (accessed on 21 January 2016).

67. Department of Transport. Road Freight Statistics, Table RFS0118. Empty Running by Business Type; 2014. Available online: https://www.gov.uk/government/uploads/system/uploads/attachment_data/file/ 479164/rfs0118.xls (accessed on 12 May 2016).

68. ISTAT (Istituto Centrale di Statistica). Trasporto Marittimo, Anni 2005-2013. 2014. Available online: http://www.istat.it/it/archivio/140422 (accessed on 12 May 2016).

69. Kristensen, H.O. Cargo Transport by sea and Road-Technical and Economical Environmental Factors. Nav. Eng. J. 2006, 118, 115-129. [CrossRef]

70. ISL (Institute for Shipping economics and logistics). Shipping Statistics and Market Review; ISL: Bremen, Germany, 2012; Volume 56, No 4.

71. Magelli, A. Gd alimentare, alta variabilità di quote per regioni e province. 2011. Available online: http: //multimedia.b2b24.it/Flipit/gdo_gdo_1112211938/megazine/images/9.swf (accessed on 12 May 2016).

72. Santi, E.; Elia, S. Caratterizzazione dei Consumi Energetici Nazionali delle Strutture ad uso Grande Distribuzione Commerciale. ENEA Report RdS/2010. September 2010. Available online: http://www.enea.it/it/Ricerca_sviluppo/documenti/ricerca-di-sistema-elettrico/fabbisogniconsumi-energetici/12-die-sintesi.pdf (accessed on 12 May 2016).

73. FAOSTAT. Food Balance. Commodity Balances-Crops Primary Equivalent. 2016. Available online: http: / / faostat3.fao.org/faostat-gateway/go/to/download/FB/BC/E (accessed on 12 May 2016).

74. FAOSTAT. Food Balance. Commodity Balances-Livestock and Fish Primary Equivalent. 2016. Available online: http:/ / faostat3.fao.org/faostat-gateway/go/to/download/FB/BL/E (accessed on 12 May 2016).

75. ASSALCO. Associazione Nazionale Imprese per l'Alimentazione e la Cura degli Animali da Compagnia. Rapporto ASSALCO-ZOOMARK 2015 Alimentazione e Cura Degli Animali da Compagnia. Available online: http:/ / www.assalco.it/index.php?action=shownews\&id=1\&nid=5704 (accessed on 12 May 2016).

76. FAOSTAT. Production. 2016. Available online: http://faostat.fao.org/site/368/default.aspx (accessed on 12 May 2016).

77. ASSALZOO. Associazione Nazionale Produttori Alimenti Zootecnici. Annuario 2015. Available online: http://www.assalzoo.it/source/annuario/ANNUARIO_2015.pdf (accessed on 12 May 2016).

78. FAOSTAT. Trade. 2016. Available online: http://faostat3.fao.org/download/T/TP/E (accessed on 12 May 2016).

79. FIGIS. Food and Agriculture Organization. Fisheries and Aquaculture Department. Fishery Commodity and Trade. 2016. Available online: http://www.fao.org/fishery/statistics/global-commodities-production/en (accessed on 12 May 2016).

80. MPAAF (Ministero delle Politiche Agricole Alimentari e Forestali). Piano di Settore per la Filiera Pataticola. 2012. Available online: http://www.politicheagricole.it/flex/cm/pages/ServeAttachment.php/L/IT/D/ a\%252F3\%252Fe\%252FD.520b1e381283cead7d34/P/BLOB\%3AID\%3D5144 (accessed on 12 May 2016).

81. ISMEA (Istituto di Servizi per il Mercato Agricolo e Alimentare). Acquisti Domestici: Ortaggi trasformati. N.10. 2000-2004. 2006. Available online: http:/ /www.ismea.it (accessed on 12 May 2016). 
82. ISMEA (Istituto di Servizi per il Mercato Agricolo e Alimentare). Acquisti Domestici: Ortaggi Freschi. N.11. 2000-2004. 2006. Available online: http:/ / www.ismea.it (accessed on 12 May 2016).

83. ISMEA (Istituto di Servizi per il Mercato Agricolo e Alimentare). Il Mercato dell'Ortofrutta. Tendenze e Prospettive. 2006. Available online: http:/ /www.ismea.it (accessed on 12 May 2016).

84. AIJN. Liquid Fruit Market Report 2014; European Fruit Juice Association: Brussels, Belgium, 2014. Available online: http:/ / viewer.zmags.com/publication/b1ade2b9 (accessed on 12 May 2016).

85. Unaitalia. Le Uova da Consumo Anno 2012. Available online: http://www.unaitalia.com/it-it/ilmercato/ datiannuali.aspx (accessed on 12 May 2016).

86. FAOSTAT. Food Balance Sheets. 2016. Available online: http://faostat3.fao.org/download/Q/QL/E (accessed on 12 May 2016).

87. Federdistribuzione. La Distribuzione in Italia, La Rete di Vendita della Distribuzione Moderna nelle Regioni italiane. 2012. Available online: http://www.federdistribuzione.it/lamappa_distributiva.php (accessed on 12 May 2016).

88. Gustavsson, J.; Cederberg, C.; Sonesson, U.; Emanuelsson, A. The Methodology of the FAO Study: Global Food Losses and Food Waste-Extent Causes and Prevention-FAO 2011; SIK Report; No. 587, January 2013; Food and Agriculture Organization of the United Nations: Rome, Italy, 2013.

89. Smith, J.A.; Yonts, C.D.; Palm, K.L. Filed loss from sugar beet harvest operations. Appl. Eng. Agric. 1999, 15, 627-631. [CrossRef]

90. Huijbregts, T.; Legrand, G.; Hoffman, C.; Olsson, R.; Olsson, Å. Long-Term Storage of Sugar Beet in North-West Europe. Coordination Beet Research International. Report Np. 1-2013. 2013. Available online: http://www.nordicbeet.nu/public_site/webroot/cache/media/file/COBRI_Storage_ Report_12013small.pdf (accessed on 12 May 2016).

91. IGD. Case Study: Tesco and Silver Spoon-Sugar Waste. IGD: City, Country, 2012. Available online: http://www.igd.com/Research/Supply-chain/Waste-prevention/Six-to-fix-to-prevent-waste/ Process/Tesco-and-Silver-Spoon---Sugar-waste/ (accessed on 12 May 2016).

92. Castellucci, F.; Iasiello, B.; Magalhaes, V.; Aigrain, P. OIV Vine and Wine Outlook 2008-2009, World Viticultural Statistics. 2013. Available online: http://www.oiv.int/public/medias/2778/oivstatistiques20082009.pdf (accessed on 12 May 2016).

93. Hamilton, J.D. Causes and consequences of the oil shock of 2007-2008. In Brooking Papers on Economic Activity. Spring 2009; pp. 215-259. Available online: http://www.brookings.edu/ (accessed on 12 May 2016).

94. Sanfilippo, S.; Ruggeri, B. LCA Alimentazione: Stima del consumo energetico per la produzione, il trasporto e la preparazione del cibo in Italia. Riv. Sci. dell'Aliment. 2009, 38, 1-16.

95. WARM, “Waste Reduction Model”. U.S. Environmental Protection Agency. June 2014. Available online: http:/ / epa.gov/epawaste/conserve/tools/warm/pdfs/Energy_Impacts.pdf (accessed on 12 May 2016).

96. Coley, D.A.; Goodliffe, E.; Macdiarmid, J. The embodied energy of food: The role of diet. Energy Policy 1998, $26,455-459$.

97. Carlsson-Kanyama, A. Climate change and dietary choices-How can emissions of greenhouse gases from food consumption be reduced? Food Policy 1998, 23, 277-293. [CrossRef]

98. Environdec. Environmental Product Declaration of Various Italian Food Products. 2008-2014. Available online: http:/ / www.environdec.com (accessed on 21 January 2016).

99. Del Borghi, A.; Gallo, M.; Strazza, C.; Del Borghi, M. An evaluation of environmental sustainability in the food industry through Life Cycle Assessment: The case study of tomato products supply chain. J. Clean. Pord. 2014, 78, 121-130. [CrossRef]

100. Pagani, M.; Vittuari, M.; Johnson, T.J.; De Menna, F. An assessment of the energy footprint of dairy farms in Missouri and Emilia-Romagna. Agric. Syst. 2016, 145, 116-126. [CrossRef]

101. Pagani, M.; Vittuari, M.; Falasconi, L. Does packaging matter? Energy consumption of pre-packed salads. Br. Food J. 2015, 117, 1961-1980. [CrossRef]

102. ISTAT (Istituto Centrale di Statistica). Energia Elettrica da Fonti Rinnovabili 2011. 2015. Available online: http:/ / dati.istat.it/Index.aspx?DataSetCode=DCCV_PRODENERG\&Lang= (accessed on 12 May 2016).

103. FEFCO. European Database for Corrugated Board Life Cycle Studies. Cepi Container Board. 2012. Available online: http://www.fefco.org/sites/default/files/documents/LCA\%20report\%202012_0.pdf (accessed on 12 May 2016). 
104. Usbeck, V.C.; Pflieger, J.; Sun, T. Summary Report. Life Cycle Assessment of Float Glass, PE International. 2011. Available online: http://www.glassforeurope.com/images/cont/184_33890_file.pdf (accessed on 12 May 2016).

105. Morawicki, R.O. Handbook of Sustainability for the Food Science; Wiley Blackwell: Hoboken, NJ, USA, 2012; p. 294.

106. Da Silva, N.; d'Souza, N.; Binder, M. Life Cycle Impact Assessment of Aluminum Beverage Cans. 2010. Available online: http://www.container-recycling.org/assets/pdfs/aluminum/LCA-2010AluminumAssoc.pdf (accessed on 12 May 2016).

107. WSA (World Steel Association). Life Cycle Assessment Methodology Report. Life Cycle Inventory Study for Steel Products; WSA: Brussels, Belgium, 2011; Available online: http://www.worldsteel.org/dms/ internetDocumentList/bookshop/LCA-Methodology-Report/document/LCA\%20Methodology\% 20Report.pdf (accessed on 12 May 2016).

108. Plastics Europe. Eco-Profiles of the European Plastics Manufacturers. Polyurethane Rigid Foam (PUR). 2005. Available online: http:/ / www.plasticseurope.org/plastics-sustainability-14017/eco-profiles/browse-bylist.aspx (accessed on 12 May 2016).

109. Plastics Europe. Environmental Product Declaration of the European Plastic Industry, Polyvinylchloride (PVC). 2008. Available online: http:/ / www.plasticseurope.org/plastics-sustainability-14017/eco-profiles/ browse-by-list.aspx (accessed on 12 May 2016).

110. Plastics Europe. Eco-Profiles of the European Plastics Manufacturers. Polyethylene Terephthalate (PET) Bottle Grade. 2011. Available online: http:/ /www.plasticseurope.org/plastics-sustainability-14017/ecoprofiles/browse-by-list.aspx (accessed on 12 May 2016).

111. Plastics Europe. Environmental Product Declaration of the European Plastic Industry, General Purpose Polystyrene (GPPS) and High Impact Polystyrene (HIPS). 2012a. Available online: http: //www.plasticseurope.org/plastics-sustainability-14017/eco-profiles/browse-by-list.aspx (accessed on 12 May 2016).

112. Plastics Europe. Plastics-The Facts 2012. An Analysis of European Plastics Production Demand and Waste Data for 2011. 2012b. Available online: http://www.plasticseurope.org/documents/document/ 20121120170458-final_plasticsthefacts_nov2012_en_web_resolution.pdf (accessed on 12 May 2016).

(C) 2016 by the authors; licensee MDPI, Basel, Switzerland. This article is an open access article distributed under the terms and conditions of the Creative Commons Attribution (CC-BY) license (http://creativecommons.org/licenses/by/4.0/). 